\title{
A Review of the Generalities of Burns Care and the Introduction of a Leading Military Hospital in the Management of Burned Patients
}

\author{
Haghshenas. $\mathrm{M}^{1}$ \\ ${ }^{*}$ Farsi. $Z^{2}$ \\ Aminian. $\mathrm{N}^{3}$ \\ 1- MSC in Nursing, Faculty of \\ Nursing, Aja University of \\ Medical Sciences, Tehran, Iran. \\ 2- ( ${ }^{*}$ Corresponding Author) \\ Ph.D., Medical-Surgical Nursing, \\ Associate Professor, Research \\ and Community Health \\ Department, Faculty of Nursing, \\ Aja University of Medical \\ Sciences, Tehran, Iran. \\ Email: zahrafarsi@gmail.com- \\ z.farsi@ajaums.ac.ir \\ 3- MD, Infectious and Wound \\ Specialist, Shahid Dr. Chamran \\ Hospital, Tehran, Iran.
}

\begin{abstract}
Introduction: Burns can always have adverse effects mentally and physically. Many people suffer from burns each year, some of them are caused by injuries in the military. There are several treatments for burns, and skin grafting is one of the most effective ones.
\end{abstract}

Objective: The present study aimed to review the generalities of burns care and introduce the leading military hospital caring the burned patients.

Materials and Methods: In the present study, electronic databases including Medline, PubMed, Scopus, SID, Cochrane library and Google Scholar engine (Persian and English) were used between 2000 and 2019.

Results: Due to anincrease in the firepower of weapons of war, Iran's sensitive and strategic position in the region, and the existence of threats on the country's borders, the treatment of wounded veterans and those in the armed forces is of particular importance. Various surgical treatments are administered for wounds that do not respond to conservative treatments. Currently, all these methods are used in the intensive care unit of Shahid Dr. Chamran Hospital.

Discussion and Conclusion: Today, due to the advancement in science, we witness a decrease in mortality and complications resulting from burns all over the world and in Iran. Shahid Dr. Chamran Hospital, as one of the military hospitals, is one of the centers that has been a leader in thispurpose. Because of the cost burdens on additional treatment for these patients, it is recommended that a solution be devised.

Keywords: Burn, Dressing, Injury, Military, Skin grafting. 


\section{مرورى بر كليات مر اقبتى - درمانى سوختكى و معرفى يك بيمار ستان نظامى يشرو

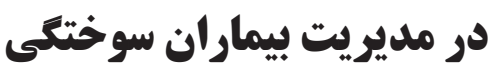

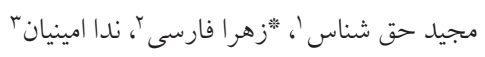

جكيده

مقدمه: سوختگى همواره مى تواند آثار و عوارض ناكوارى بر جسم و روان فرد بحذارد. سالانه افراد زيادى دجار آسيبهاى

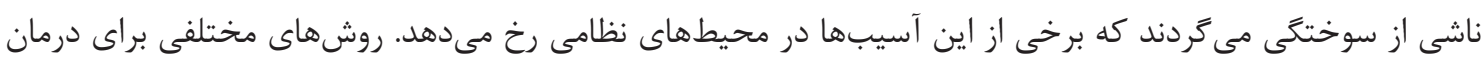

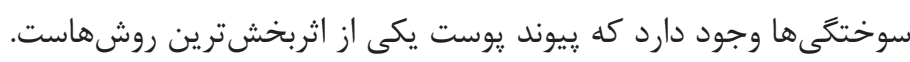

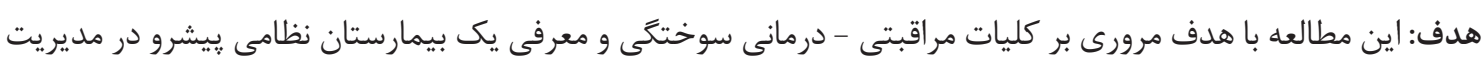
بيماران سوختخى انجام شد.

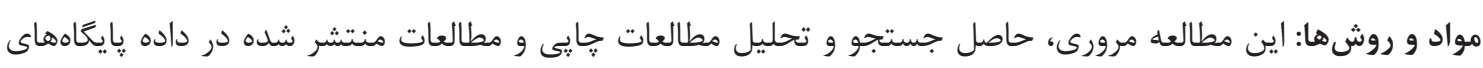

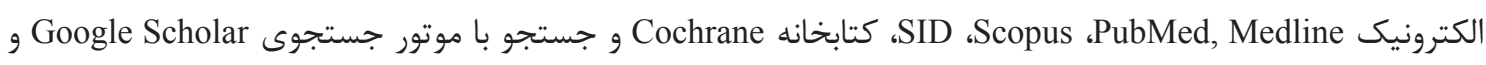

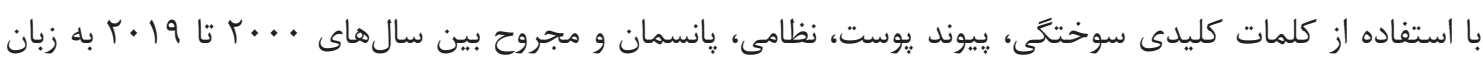
فارسى و انغليسى مىباشد.

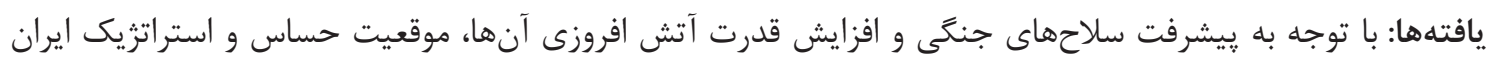

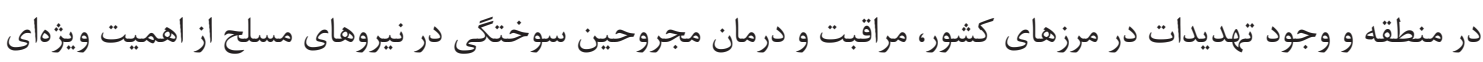

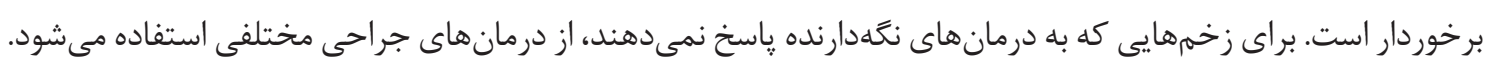

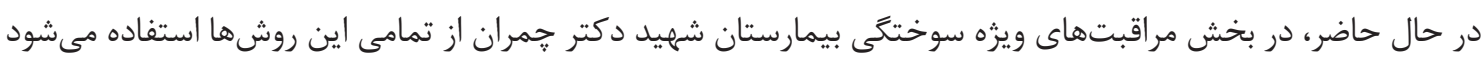
كه در متن مقاله به آنها مى حَردد.

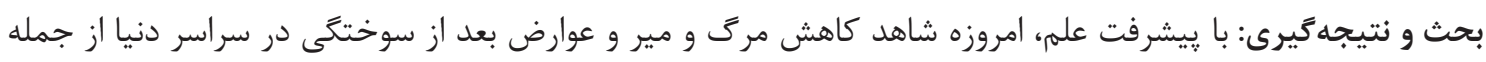

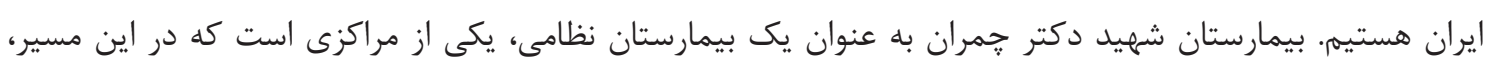

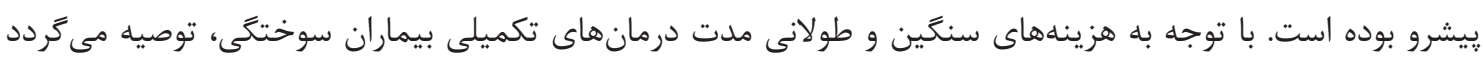

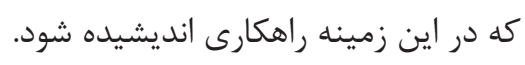

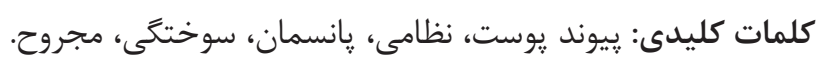

تاريخ دريافت:

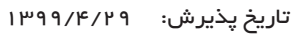

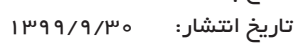

كشور ايران رخ مى دهند و امكان وقوع آنها در جوامع مختلف با مقلمهه

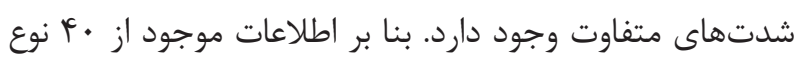
بلايا و حوادث غيرمترقبه مانند سيل، زلزله و جنَ اغلب اتفاقاتى حادثه شناخته شده در سطح جهان، اس مورد آن در ايران رجان غيرقابل كنترل مى باشند و همواره در نقاط مختلف جهان از جمله زيله 
بودهاست. حدود | |م| نفر (ه/سب درصد) نياز به حمايت ونتيلاتورى קيدا كردند كه در حدود 99 نفر آنها سوختتى استنشاقى تائيد

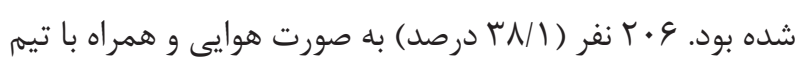

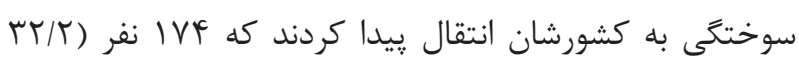

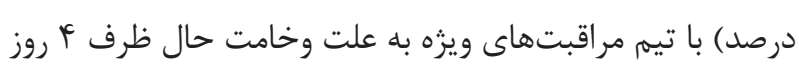

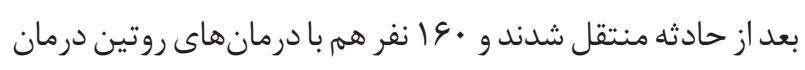

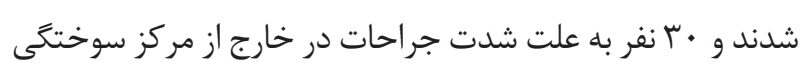

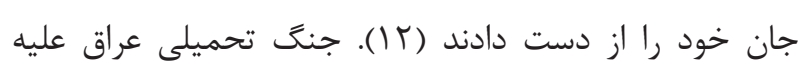

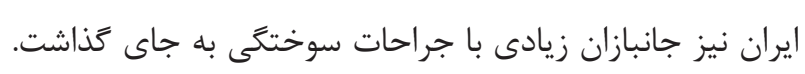
وليكن آمار دقيقى در اين خصوص در دست نيست. مطالعات زئن

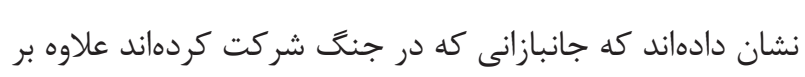

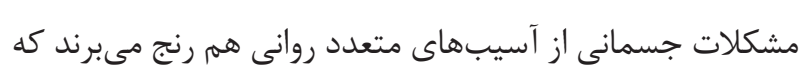

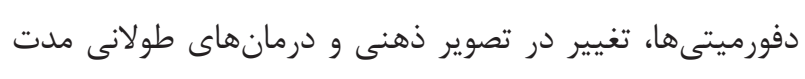

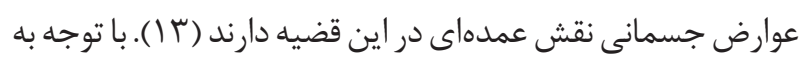

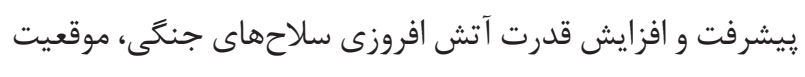
حساس و استراتزيك ايران در منطقه و وجود تهديدات در مرزهاى كشور، درمان جانبازان و مجروحين سوختكى در نيروهاى مسلح

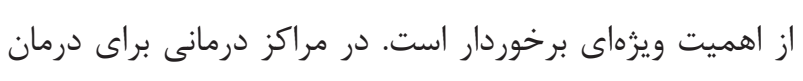

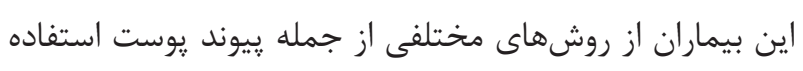

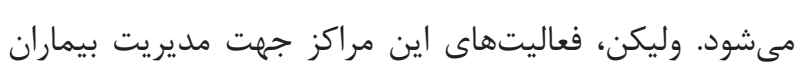

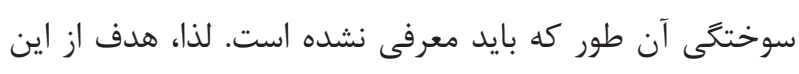

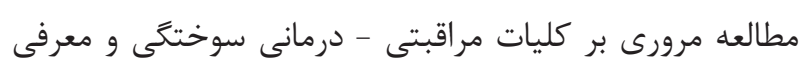

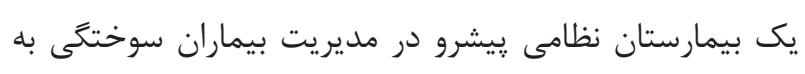
عنوان يك مركز ارجاعى مىباشد.

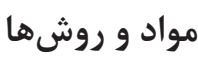

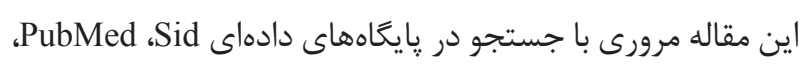
Medline ، Scopus

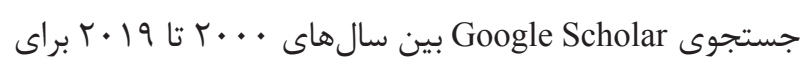
يافتن مقالات فارسى و انغليسى انجام شد. در اين جستجو از باز

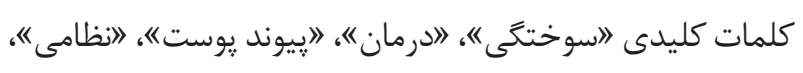

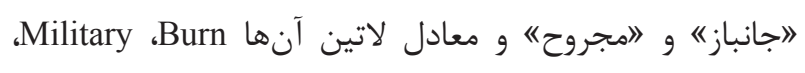
Sketeran ،Injury SKin grafting Treatment

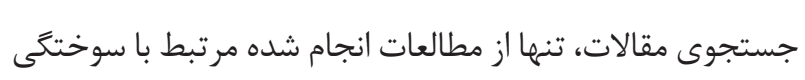

مى دهد ( ). سوختكى به عنوان يكى از آسيبهاى جدى به شمار

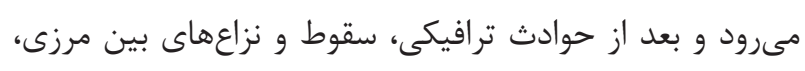

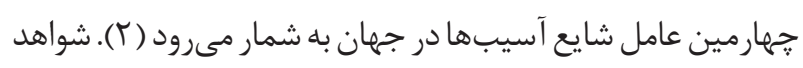

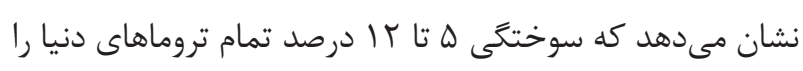

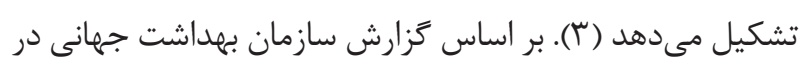

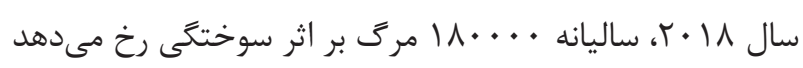

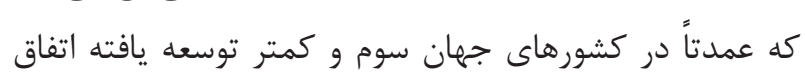

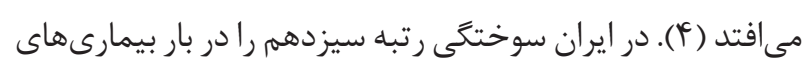

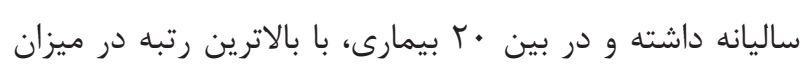

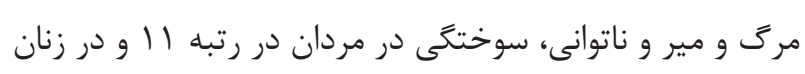

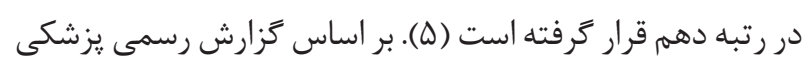

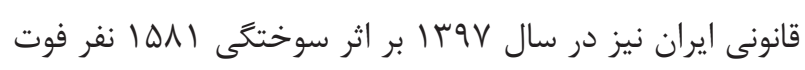
نمودهاند (9). حوادث سوختكى به عنوان يكى از نتايج جنَّها قدمتى طولانى دارد. سوختخى در مجروحين جنتى شايع است.

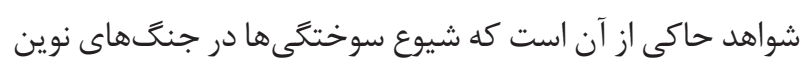
با توجه به افزايش قدرت آتش افروزى اين سلاحها افزايش يافته إنه

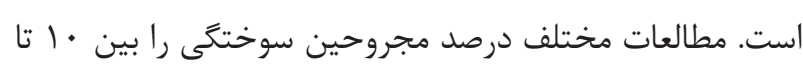

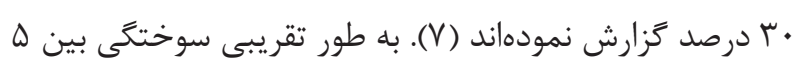

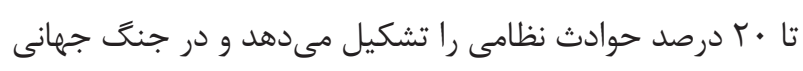

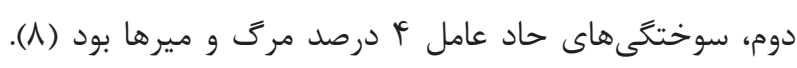

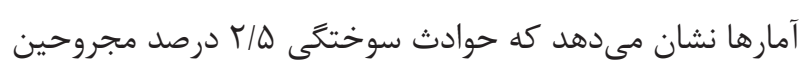

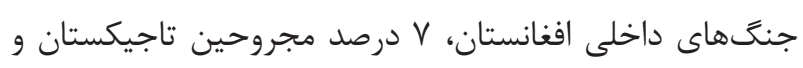

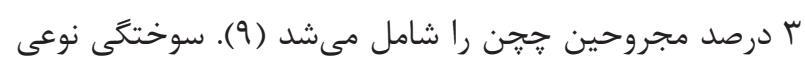

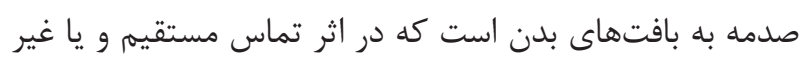

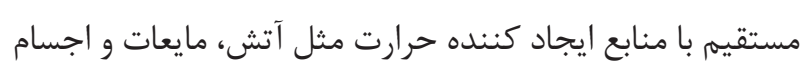
داغ، مواد شيميايى، اشعههاى خطرناك و جريان الكتر يسيته ايجاد

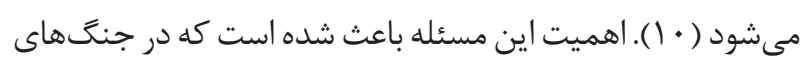

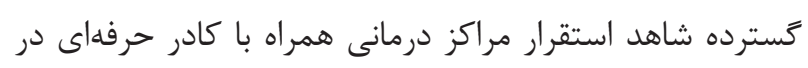
نزديكى محلهاى دركيرى باشيم كه يكى از مهمترين خدمات

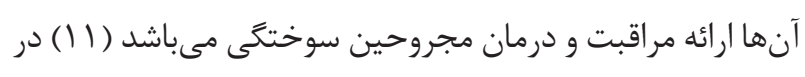

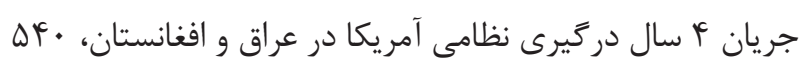

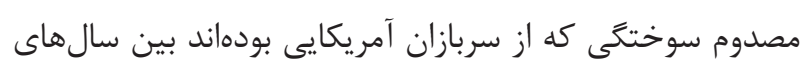

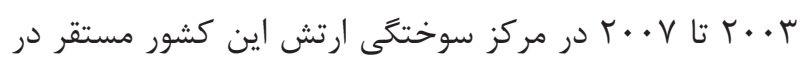

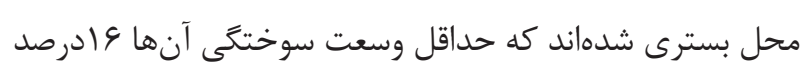


نمونه و درجه يك عالى نيروهاى مسلح جمهورى اسلامى ايران

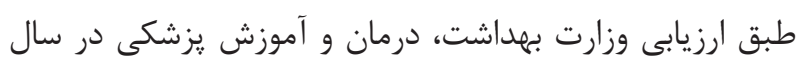

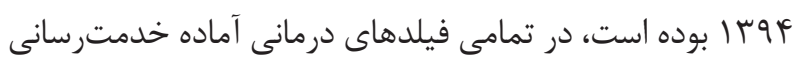

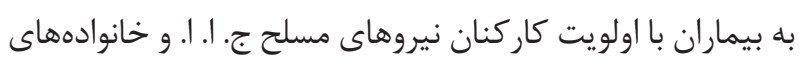

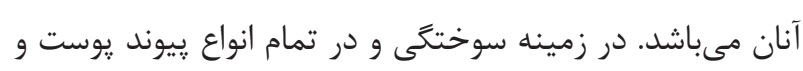

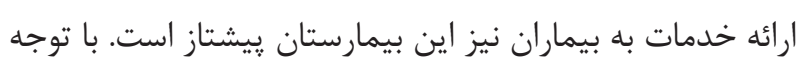

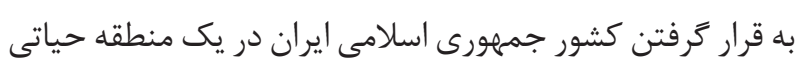

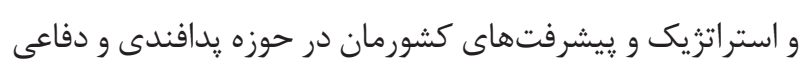

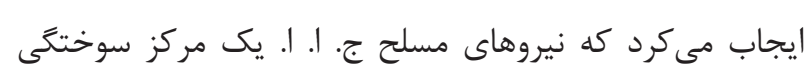

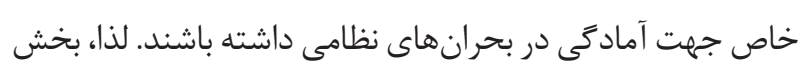

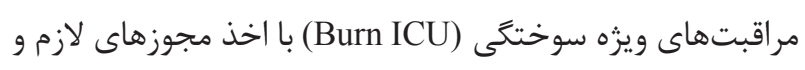

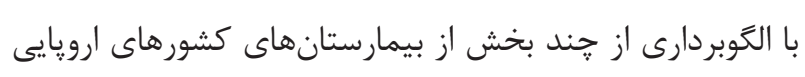

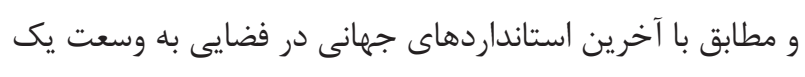

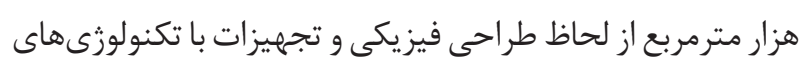

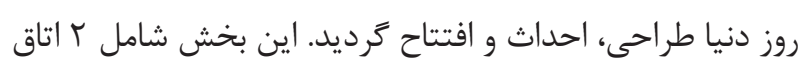

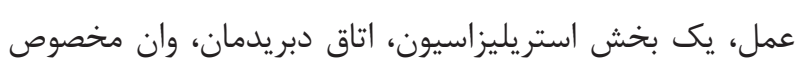

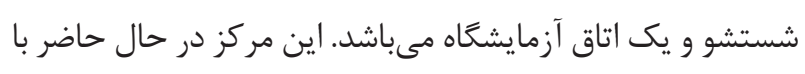

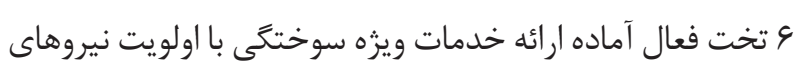

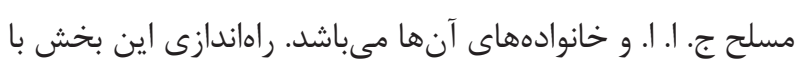

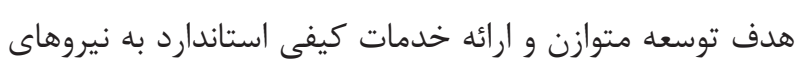

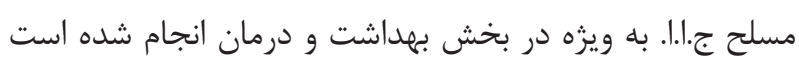

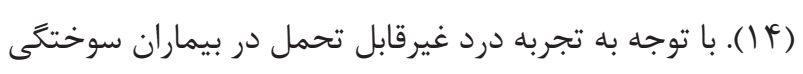

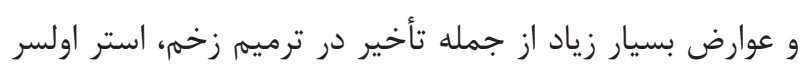

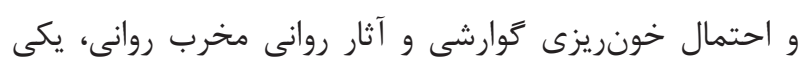

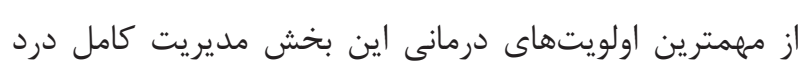

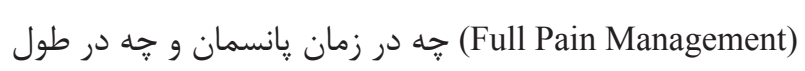
مدت بسترى در اين بخش مىباشد. مديريت كامل درد در اين

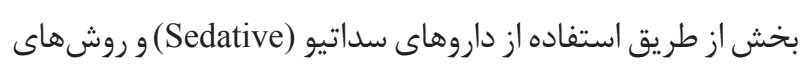
القاى هوشبرى و خواب توسط متخصصين بيهوشى انجام مى گيرد.

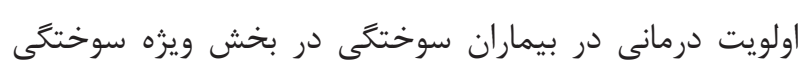

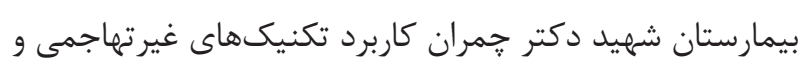

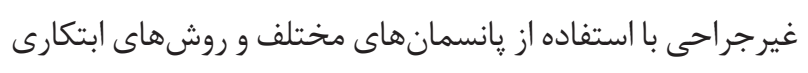

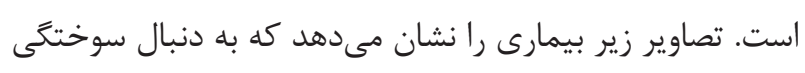

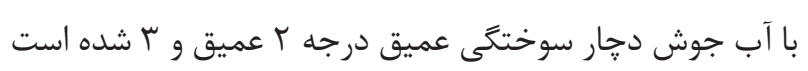

استفاده شد و مقالات صرفاً مربوط به تروما و مقالاتى كه داراى

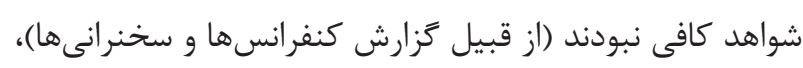

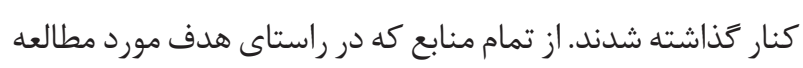

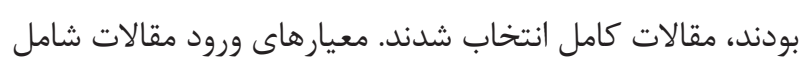
مقالات تحقيقى مرتبط با موضوع سوختگى بر اساس كلمات

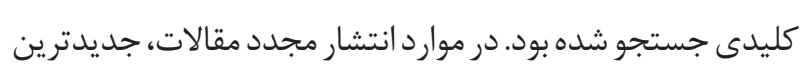

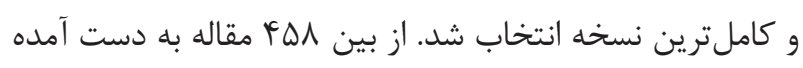

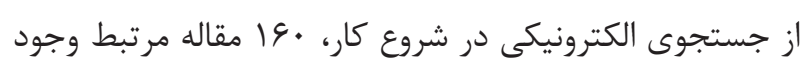
داشت كه از اين مقالات، هـ مقاله در راستاى اهداف مطالعه

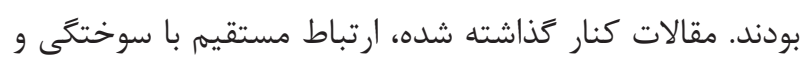
يیوند يوست نداشتند.

يافتهها در اين بخش ابتدا نكاهى كذرا به وضعيت يكى از بيمارستان هاى

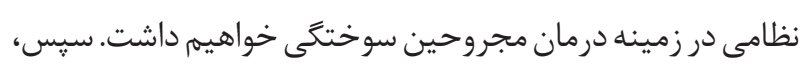

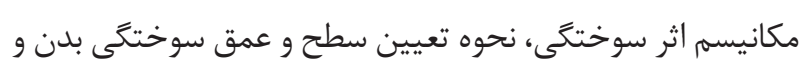

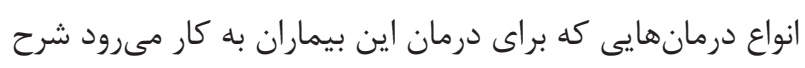

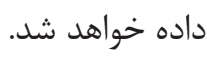

نعَاهى به وضعيت يكى از بيمارستان هاى نظامى در زمينه درمان

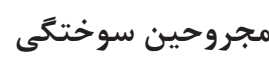

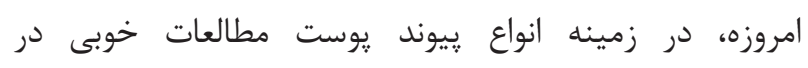
بيمارستانهاى ايران مانند بيمارستان آيت الله طالقانى اهواز، دئن بيمارستان شهيد زارع مازندران، بيمارستان شهيد مطهرى تهران

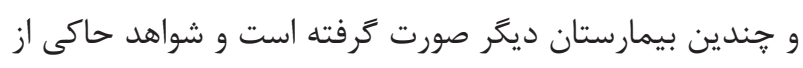
آن است كه يِشرفت جشمخيرى در اين زمينه در كشور اتفاق

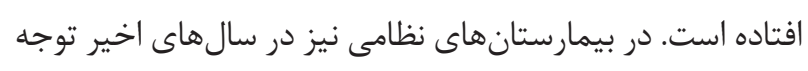

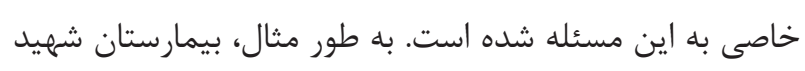

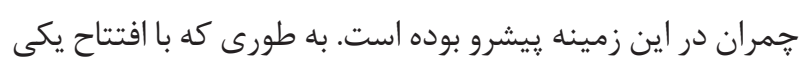
از مجهزترين و به روزترين بخشهاى ويزه سوختكى در كشور

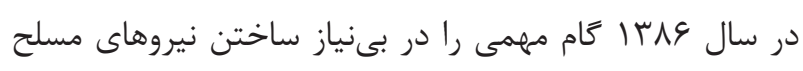
از اعزام مصدومين سوختتى نظامى با جراحات وسيع به خارج از كشور كه خطر تخليه اطلاعاتى توسط عوامل دشمن را در بردارد، برداشت. امروزه، بيمارستان شهيد جمران كه از بيمارستانهان تهريط 
اعضاء تيم سوختكى در بيمارستان شهيد دكتر خمران

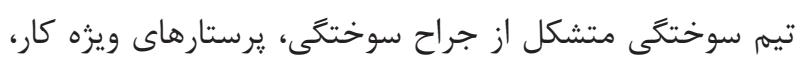
متخصصين توانبخشى و فيزيوترايى، متخصصين تغذيه، اعضاء

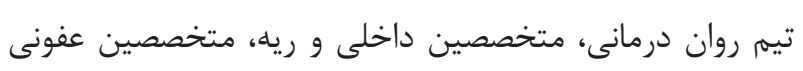

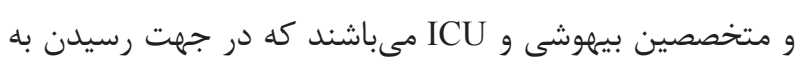

$$
\text { • اهداف زير تلاش مي كنند: }
$$

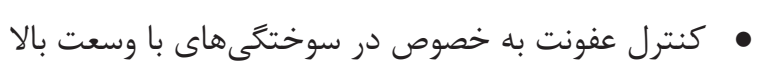

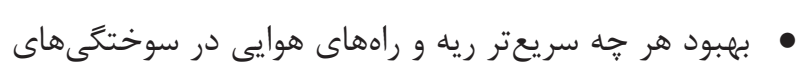

$$
\begin{aligned}
& \text { استنشاقى } \\
& \text { • حفظ وضعيت هموديناميك و سلامتى ساير اركانها } \\
& \text { • حفظ حركات فيزيكى اعضاء }
\end{aligned}
$$

كه با استفاده از يانسمانهاى مدرن و زنوگرفت بدون نياز به

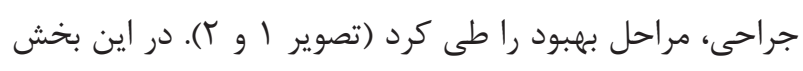

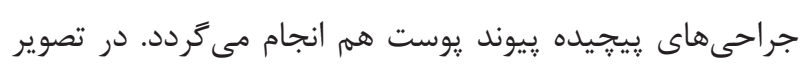

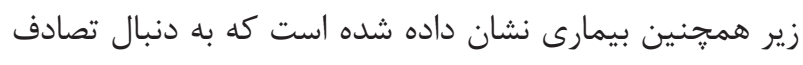

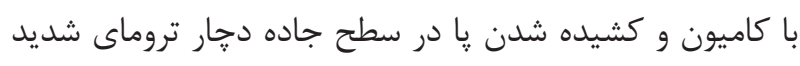

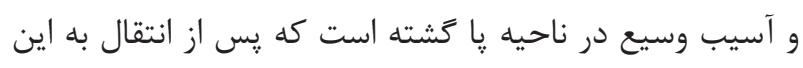

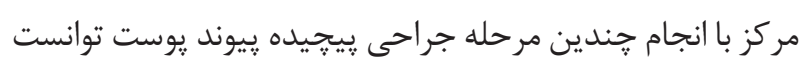
مراحل درمان را با موفقيت طى كند (تصوير ب تا ها ه).

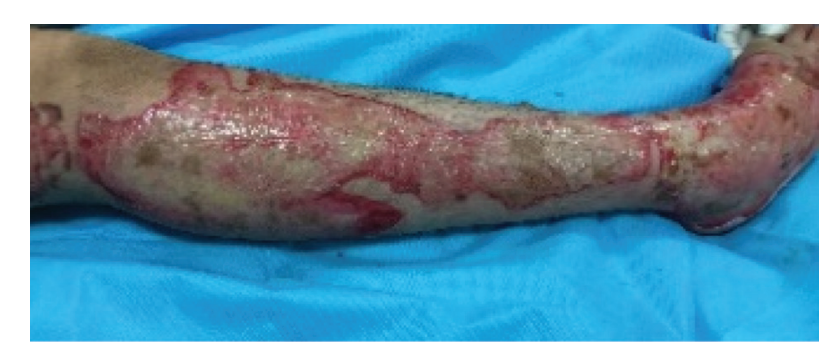

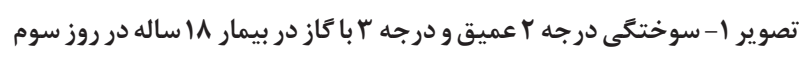

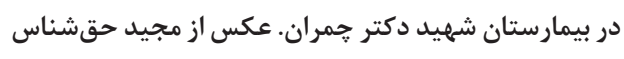

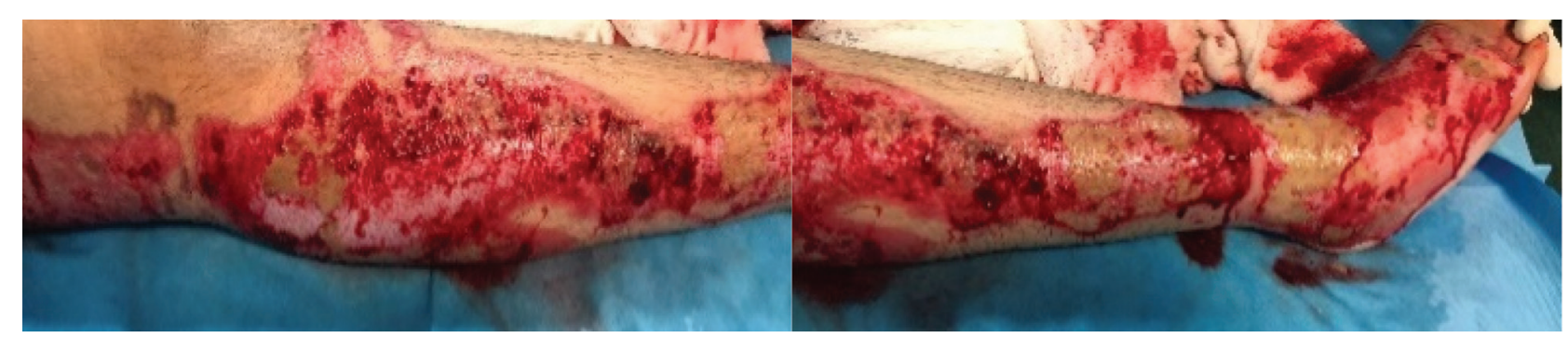

تصوير r- بيمار فوق يك هفته بعد از درمان با روشهاى غير جراحى و در حال بهببود بيدا كردن در بيمارستان شهيد دكتر حمران. عكس از مجيد حقشناس

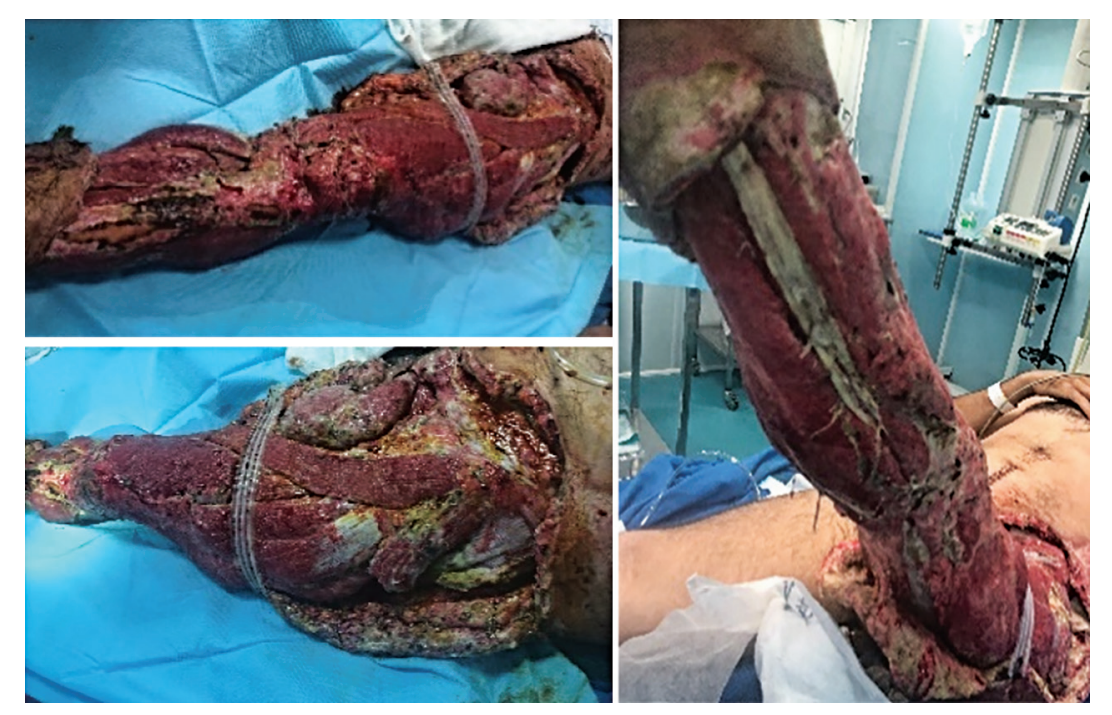

تصوير ץ- بيمار هـ ساله تصادفى با كاميون دهار آسيب شديد بافتى و يوستى قبل از عمل در بخش ويزٔه سوختكى بيمارستان شهيد دكتر حمران. عكس از مجيد 
مى تواند باعث آزاد شدن يتاسيم به فضاهاى بيرون سلول و جذب

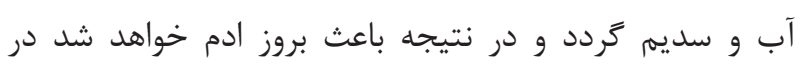

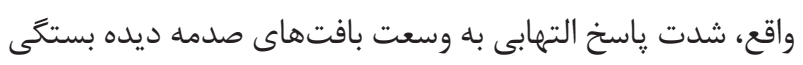

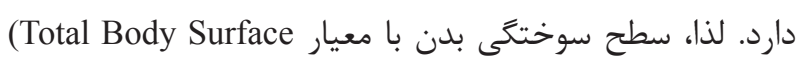
مشخص مىشود (1) (1). جنانجه TBSA Area=TBSA)

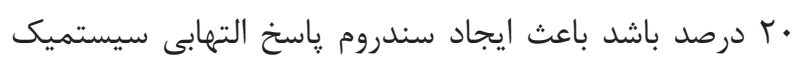
خواهد شد كه (Systemic Inflammatory Response =SIRS) در اين وضعيت مايع زيادى از فضاى درون سلولى از بين رفته

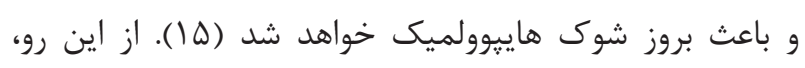

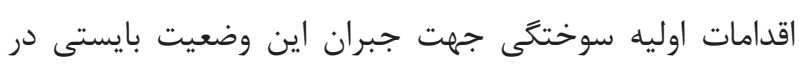

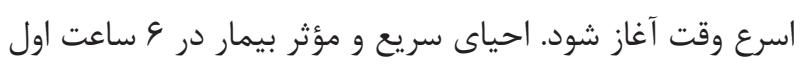

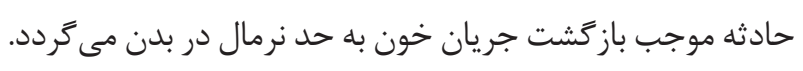

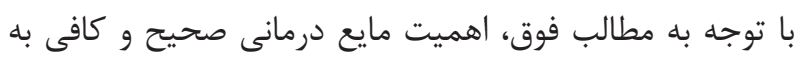

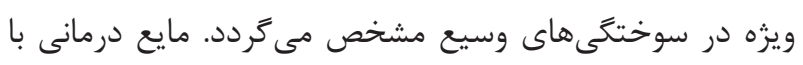

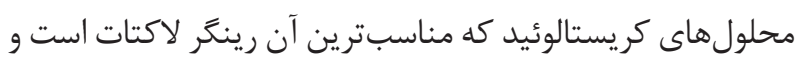

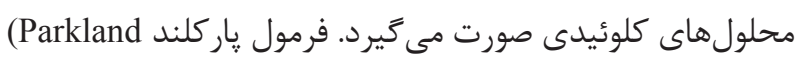

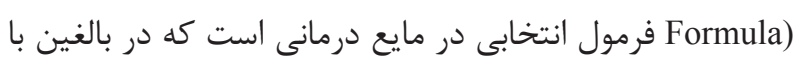

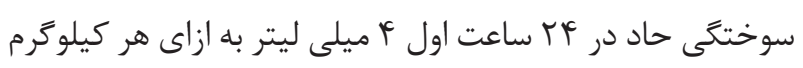

\begin{tabular}{|c|c|c|}
\hline \multicolumn{2}{|c|}{ درصد نسبت به سطح بدن } & \multirow{2}{*}{ محل آناتوميك } \\
\hline بزرَسالان & كودكان & \\
\hline$\%$ & $\% 9$ & هر يك از دستها \\
\hline$\%$ & $\% 11$ & سر و كردن \\
\hline$\% 11$ & $\% 14$ & هر يك از ياها \\
\hline$\% 11$ & $\% 11$ & قدام تنه \\
\hline$\% 11$ & $\% 11$ & خلف تنه \\
\hline$\% 1$ & $\% 1$ & رُنيتال \\
\hline
\end{tabular}

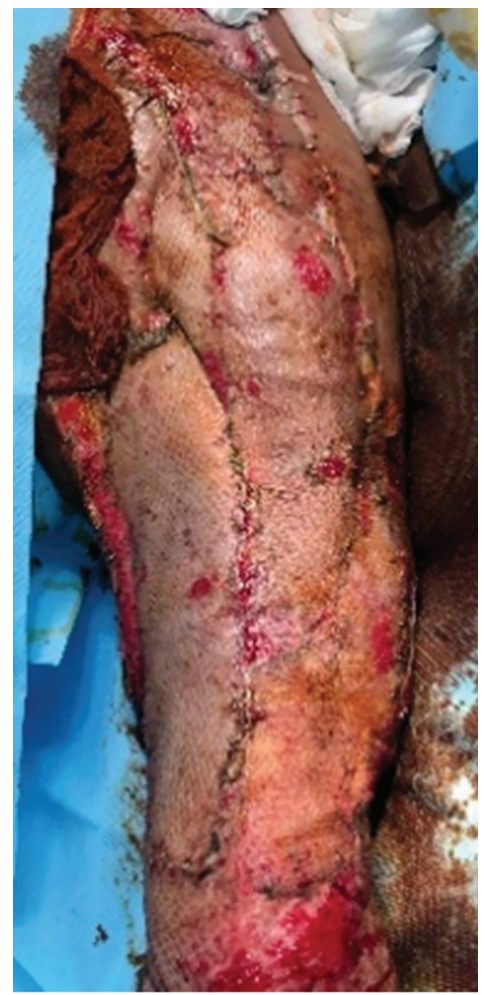

تصوير ץ- بيمار فوق جهار روز بعد از عمل در بيمارستان شهيد دكتر جمران. عكس از مجيد حقشناس • يشخَيرى از فوت بيمار در سوختخى هاى وسيع و شديد

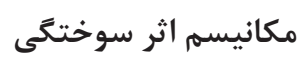

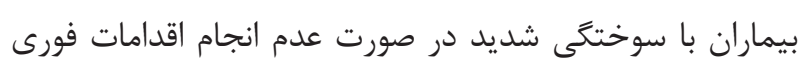

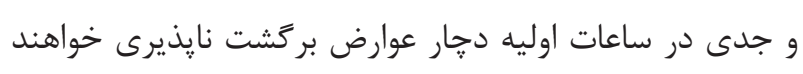

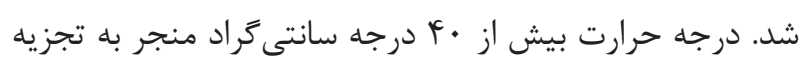

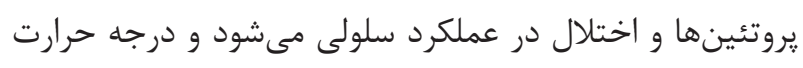

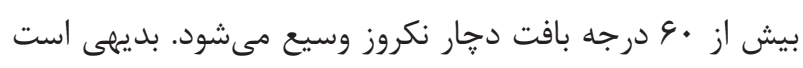

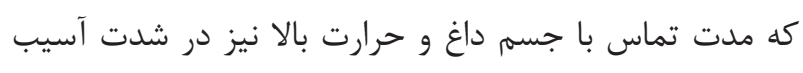

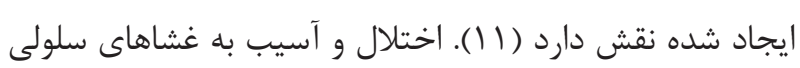
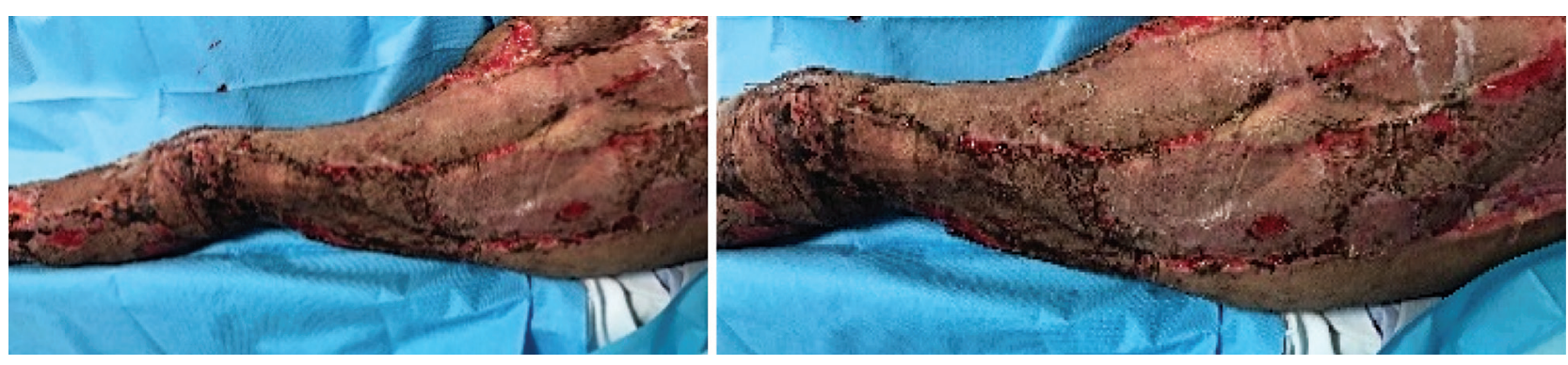

تصوير ه- همان بيمار هشت روز بعد از عمل در بيمارستان شهيد دكتر جمران. عكس از مجيد حقشناس 
مانند زخم آفتاب سوختكى. زخم درجه r سطحى كه إيدرم و

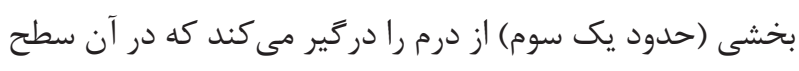

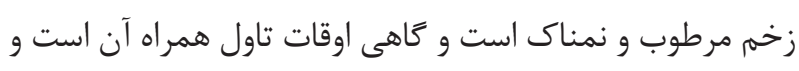

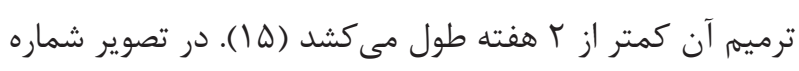

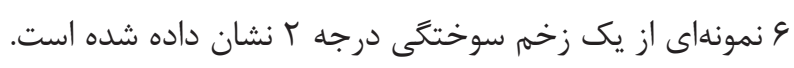

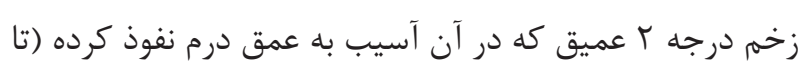

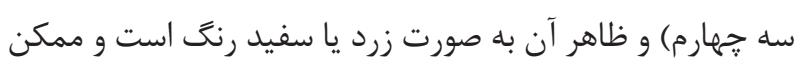
است همراه با تاول باشد و در صورت لمس با ناراحتى همراه است انت

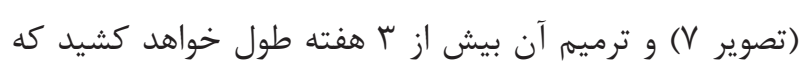

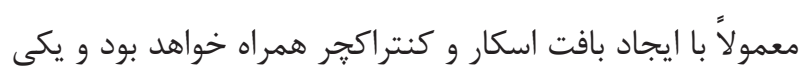

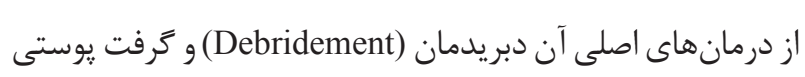

(Skin Graft) زخم درجه ب يا با ضخامت كامل كه تمام لايههاى يوست دركير

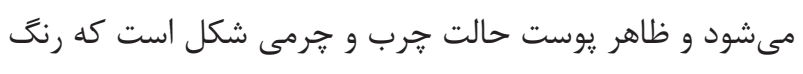

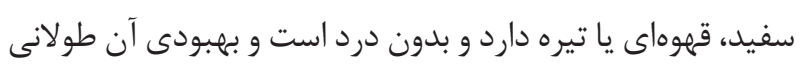

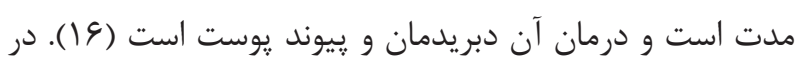

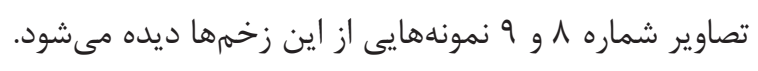

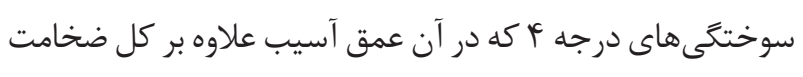

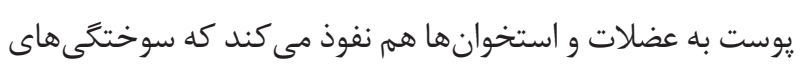
الكتريكى ولتاز بالا و سوختخى هاى انفجارى بيشتر در اين دسته

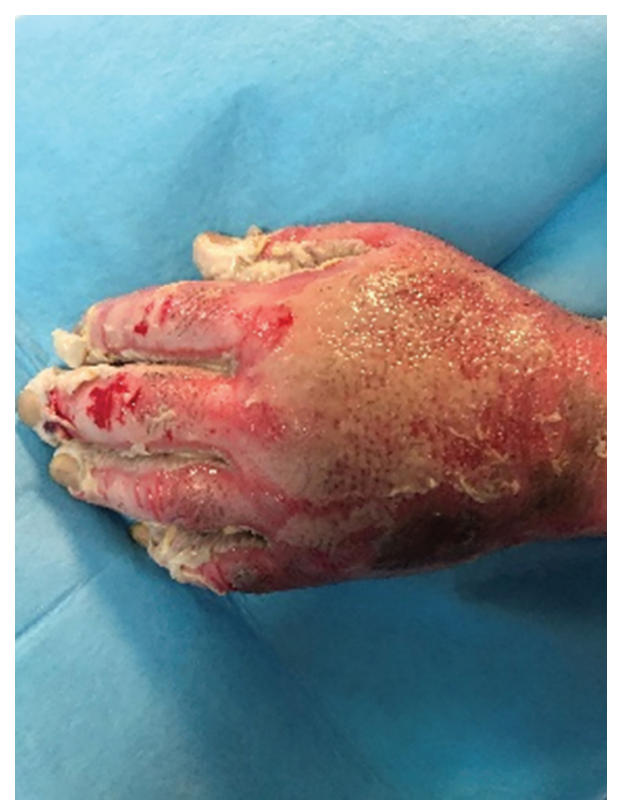

تصوير V- زخم درجه Y عميق در بيمار سوختكى هله ساله در بيمارستان شهيد دكتر جمران. عكس از مجيد حقشناس
وزن بدن ضربدر درصد سوختخى مىباشد كه نصف مايعات (رينكر

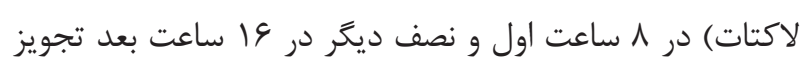

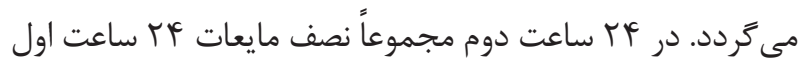

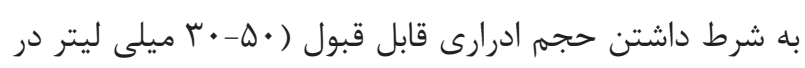
ساعت) مىباشد (1) (1).

\section{تعيين عمق سوختكى}

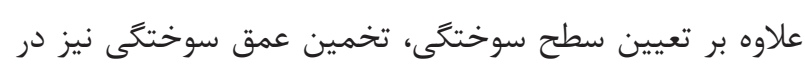

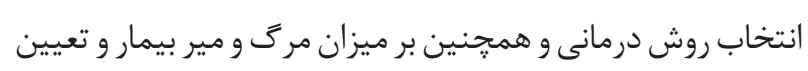

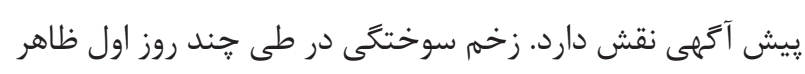

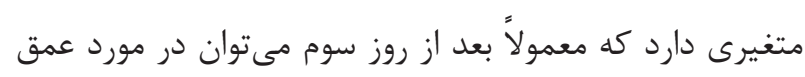

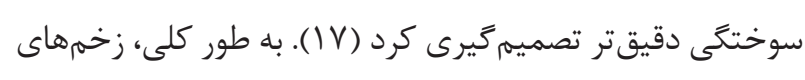

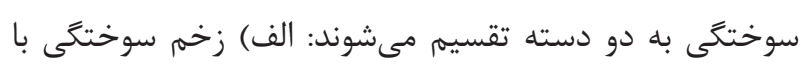
در كيرى قسمتى از ضخامت يوستى (Partial Thickness Burn) ب) زخم سوختخى با ضخامت كامل يوست (Full Thickness).

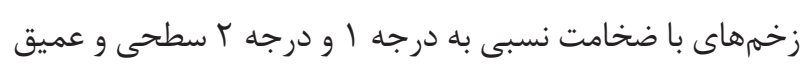

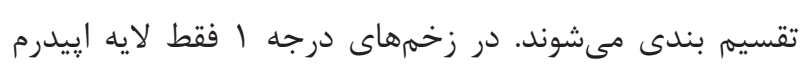

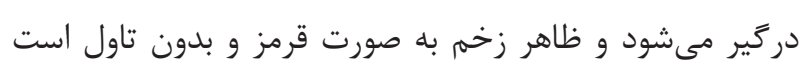

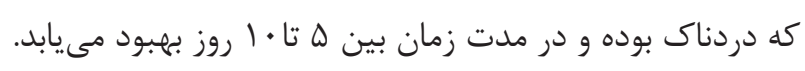

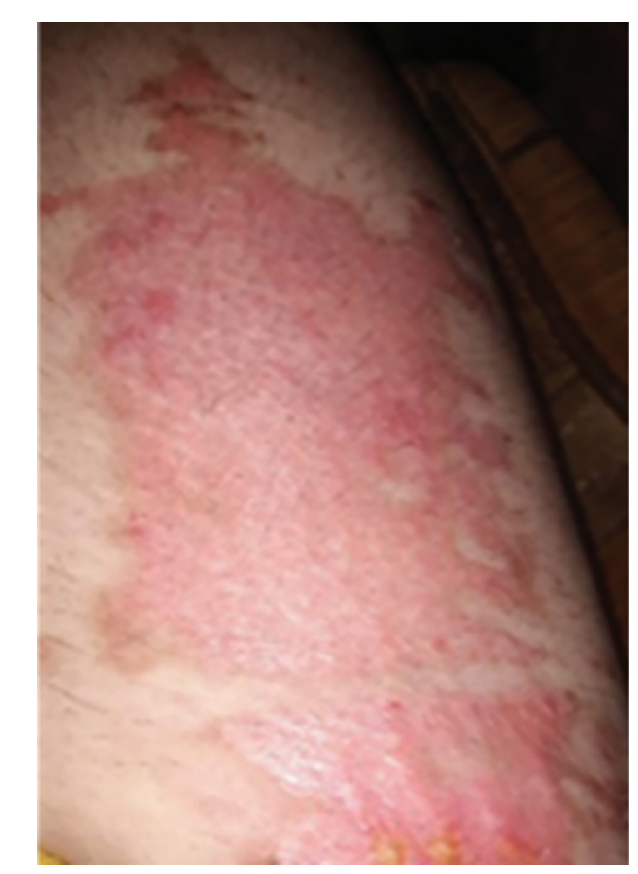

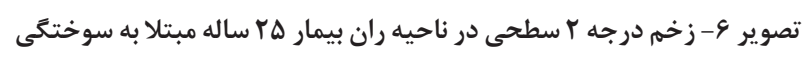

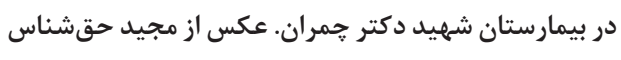




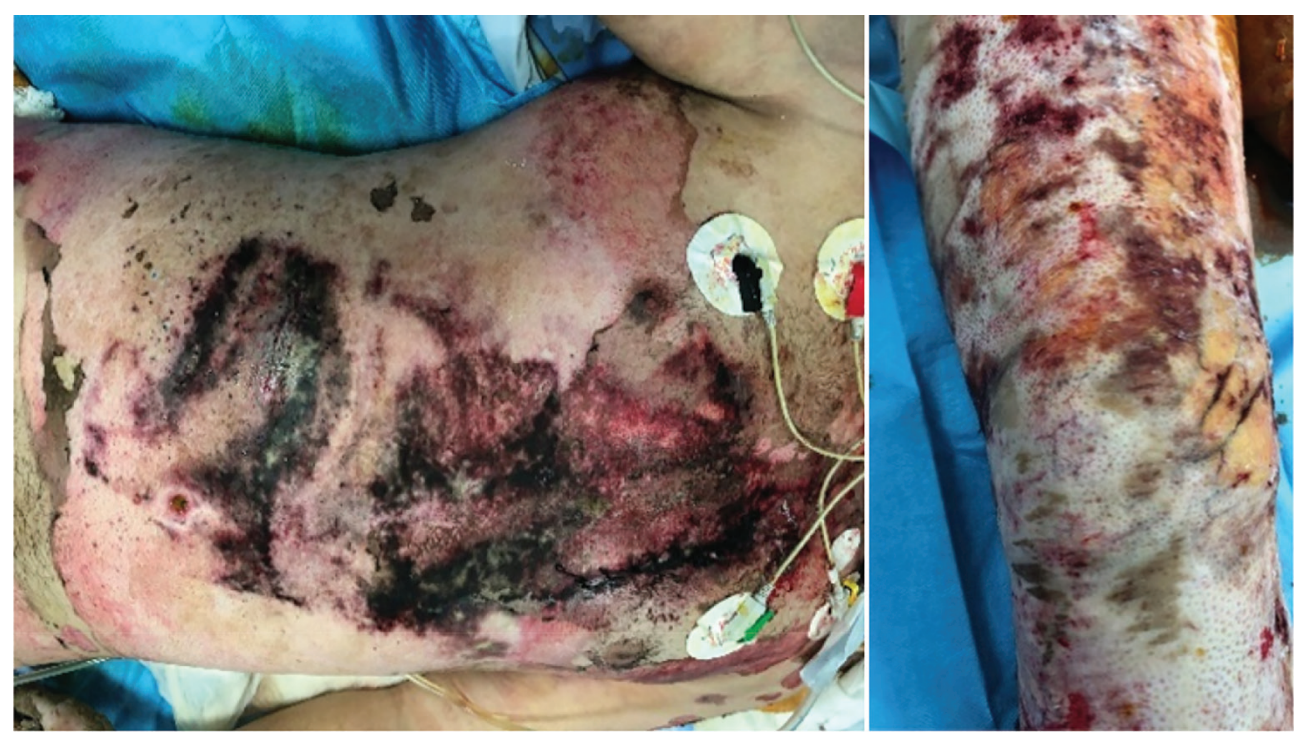

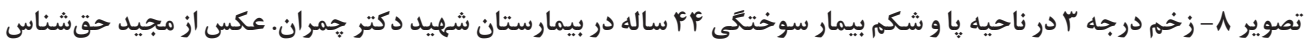

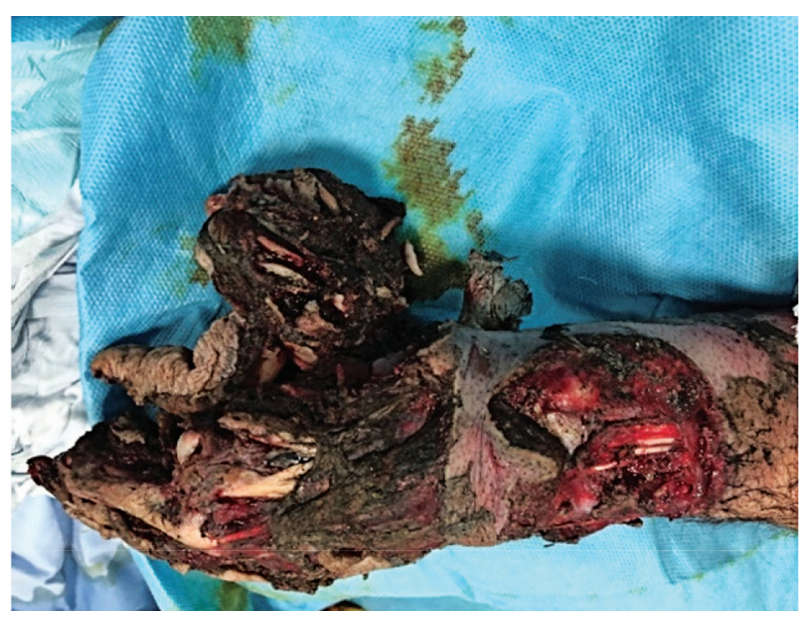

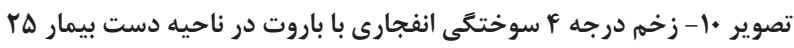

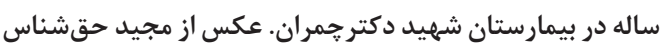

اندامها و يا قفسه سينه دركير شده باشد، زخم سوختكى مىتواند مانند تورنيكه عمل كرده و جريان خون آن عضو يا اندام را مختل كرده و يا موجب اختلال تنفسى شود. در اين بيماران بايد علائم

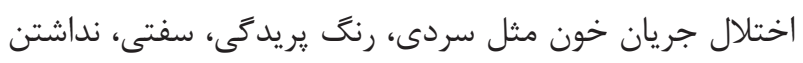

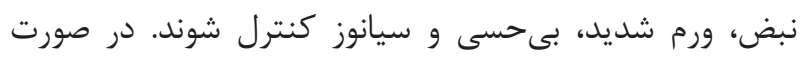

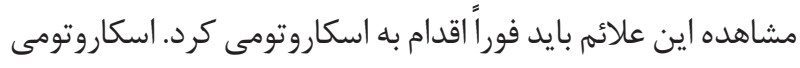
بدون درد است و حتى مى توان در اتاق يانسمان در شرايط استريل

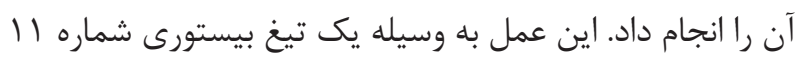

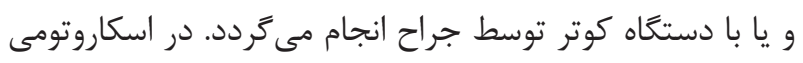

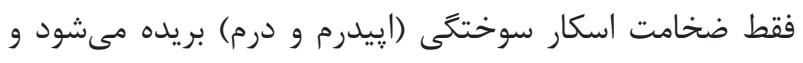

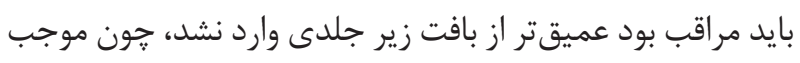

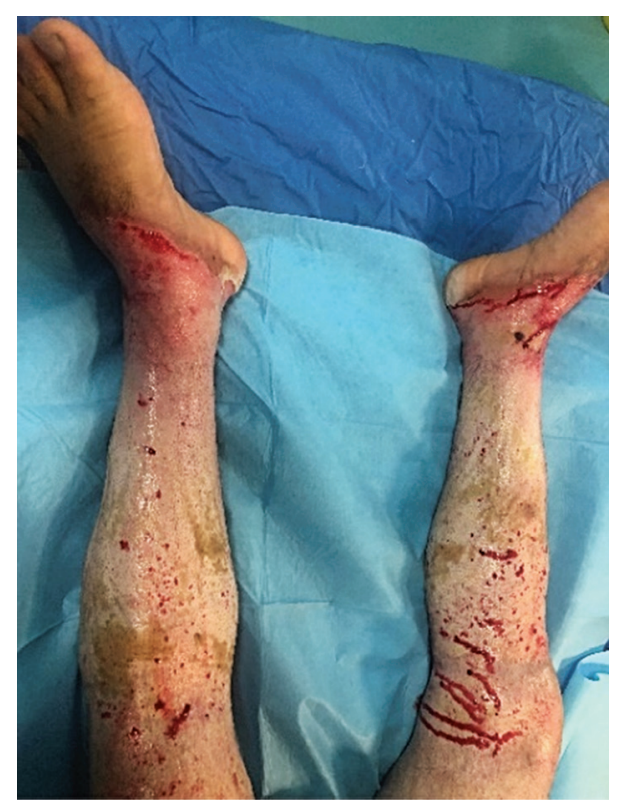

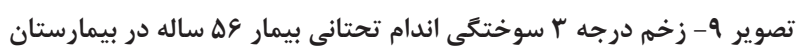

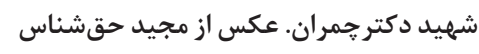

قرار مى گيرند كه در آن ظاهر قسمت آسيب ديده سياه و خشك د ن.

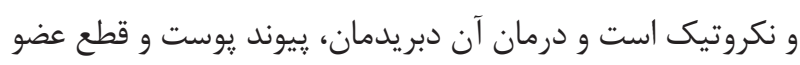
(Amputation) زخم نشان داده شده است.

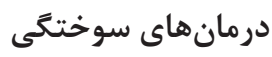

اسكاروتومى (Escharotomy) و فاشيوتومى (Fasciotomy) در سوختخى هاى عميق و وسيع درجه ب و يا درجه ب كه دور تا دور 
ضايعات عروقى و عصبى و عضلانى برگشت نايذير وجود خواهد

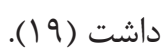

\section{ييوند يوست}

شناخت كافى از مراحل ترميم زخم نقش مهمى در گسترش ئش

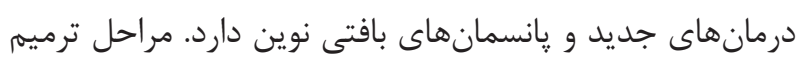

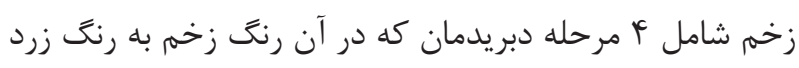

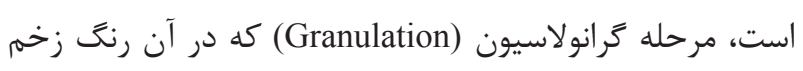

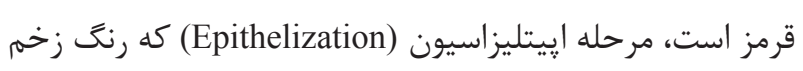

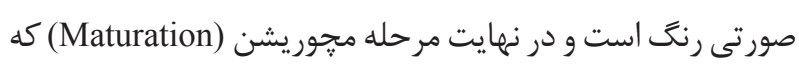

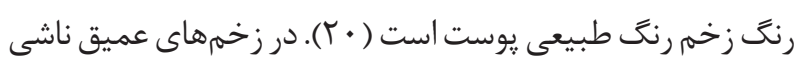

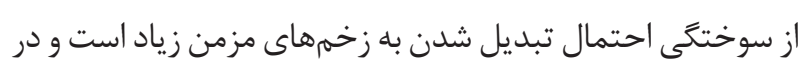

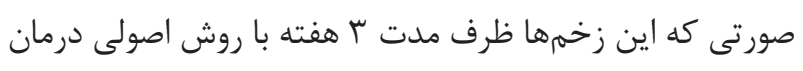

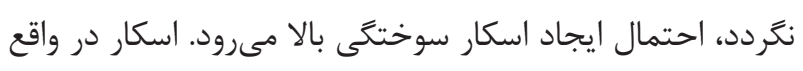
از رسوب رشتههاى كلازن، تحريك شدن مرحله إيىتليزاسيون

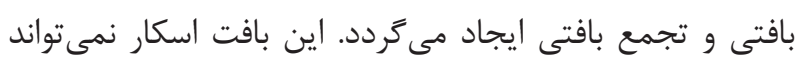

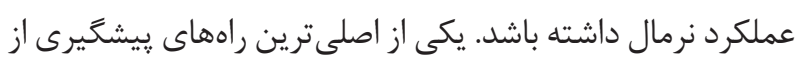

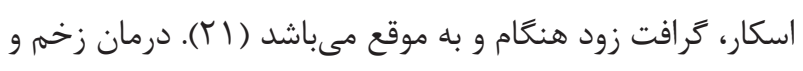
آسيب هاى يوستى مزمن برحسب عامل به وجود آورنده آن متفاوت است كه در كام نخست بايد عامل به وجود آورنده آن را رفع كرد. به طور كلى، درمانها به دو كروه كنسرواتيو (Conservative) و

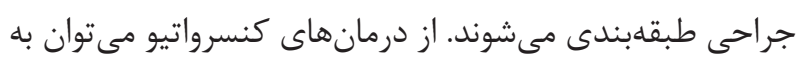

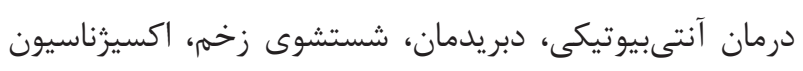

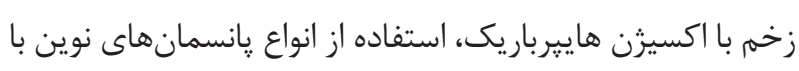
تركيب نقره، افزايش سطح فاكتورهاى ترميم كننده بافتى، ايجاد فشار منفى در محيط زخمم و ايجاد محيط مرطوب اشاره كرد. از

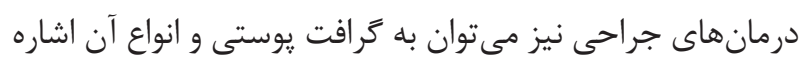

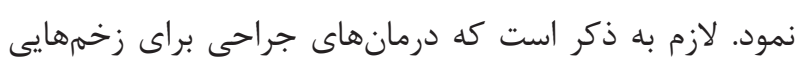

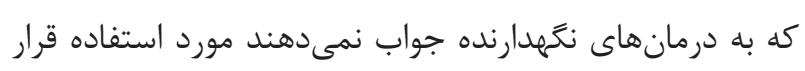
مى

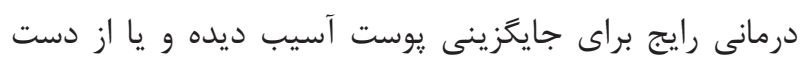

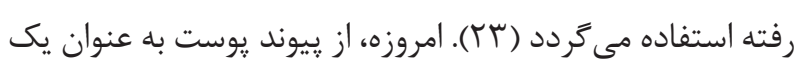

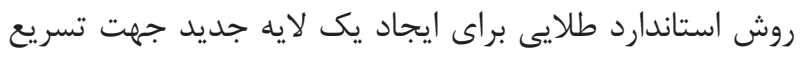

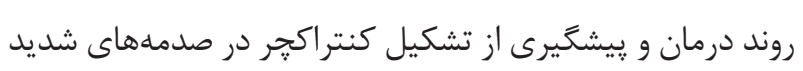

خونريزى مى

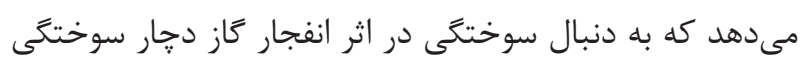

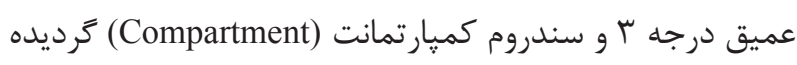

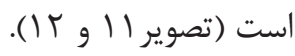

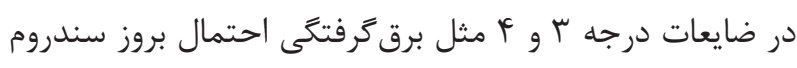

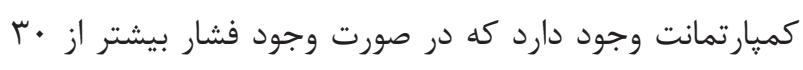

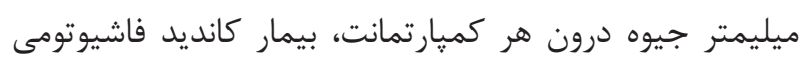

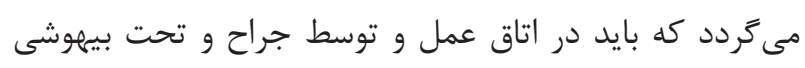
عمومى صورت مى گيرد. نكته حائز اهميت اين است كه حتماً

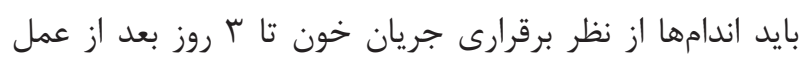
كنترل گردد. در صورت غفلت از اين مسئله احتمال بروز

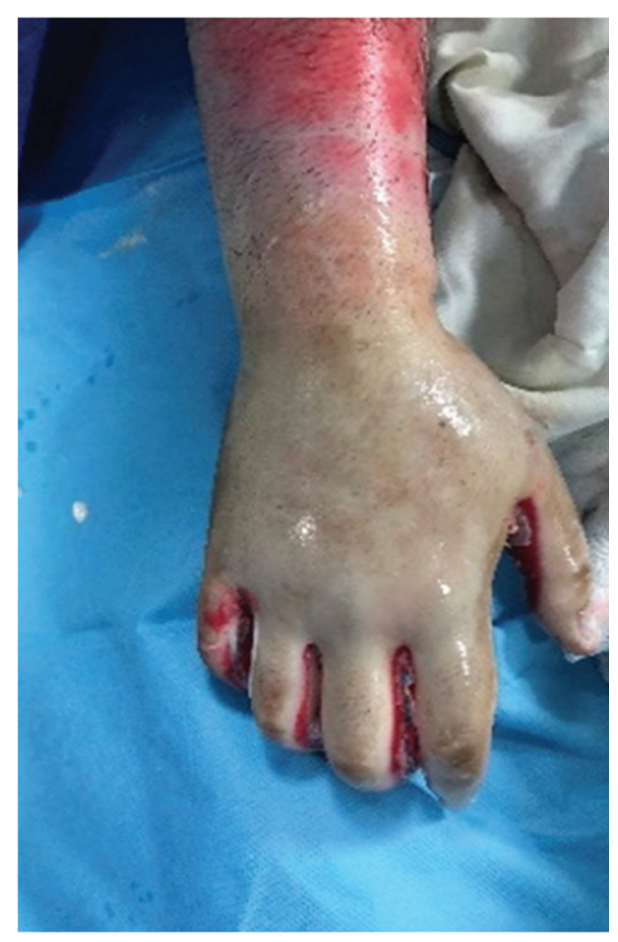

تصوير ال- سوختكى عميق در دست بيمار هـ ساله كانديد اسكاراتومى در

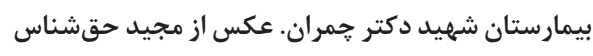

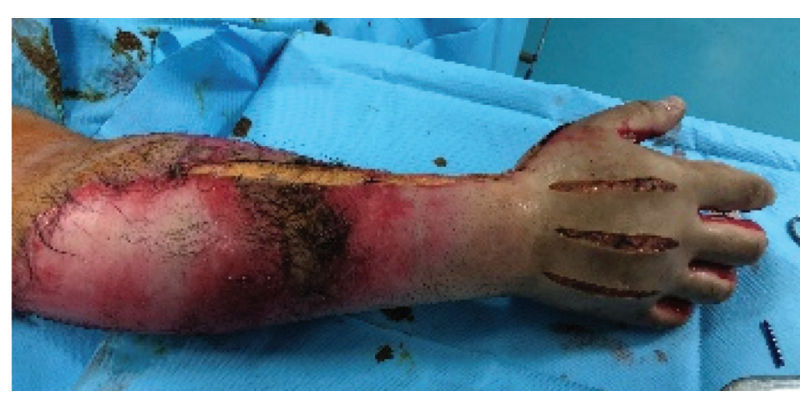

تصوير rآ- تصوير قبل بعد از انجام اسكاراتومى در بيمارستان شهيد دكتر

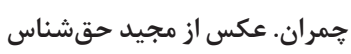


كه به جريان خون متصل است، گرافت يوستى (Skin Flap) خونرسانى نداشته و بنابر اين براى دريافت مواد مغذى به به بستر

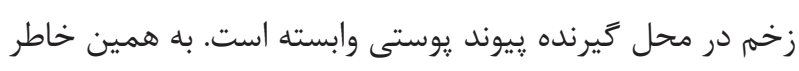

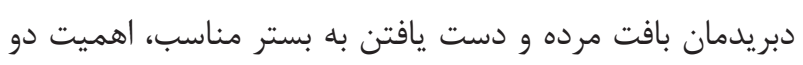

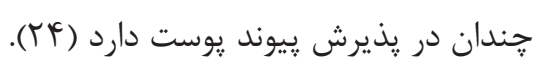

\section{مههمترين انواع كَفت يوستى}

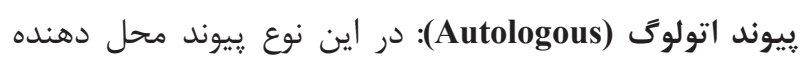

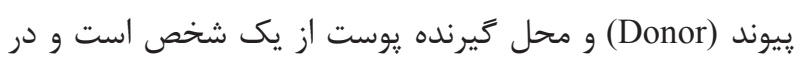
واقع يوست از يك قسمت سالم بدن برداشته و روى محل آسيب

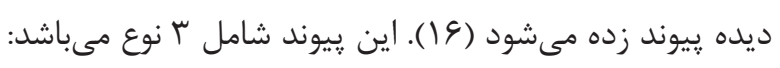
(- الف) ييوند يوست باضخامت نسبى Split-Thickness Skin) اين پييوند يك نوع پيوند يوست است كه شامل :Graft) (STSG)

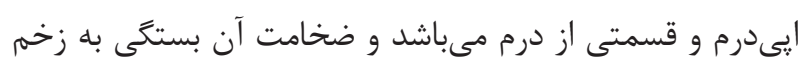

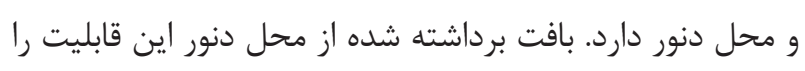

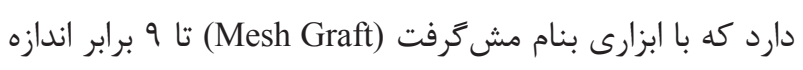

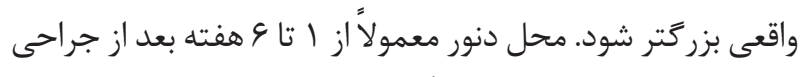

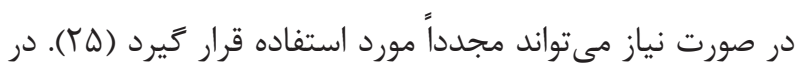

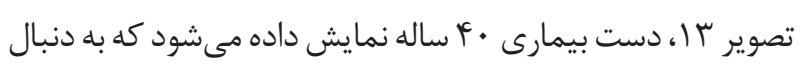

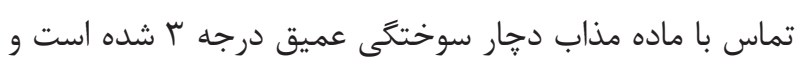

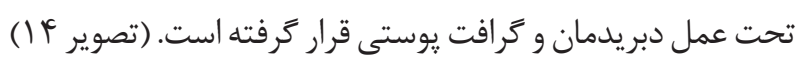

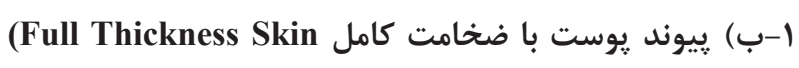
كraft)

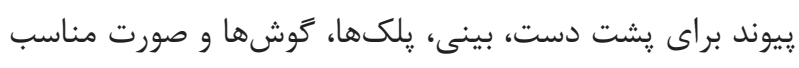

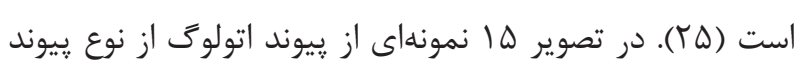

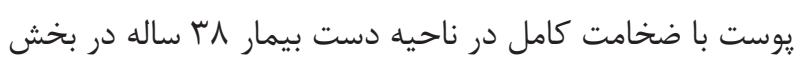

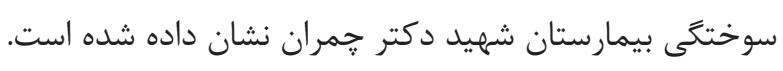

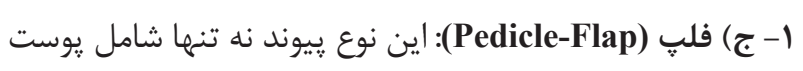
و بافت زيريوستى است، بلكه شامل عروق زير يوستى هم هست.

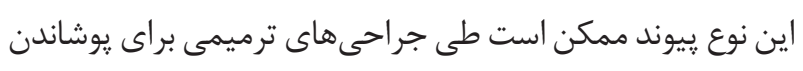

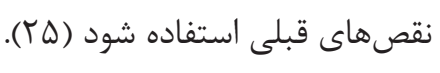

انتخاب محل دهنده يوست

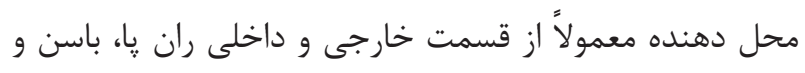

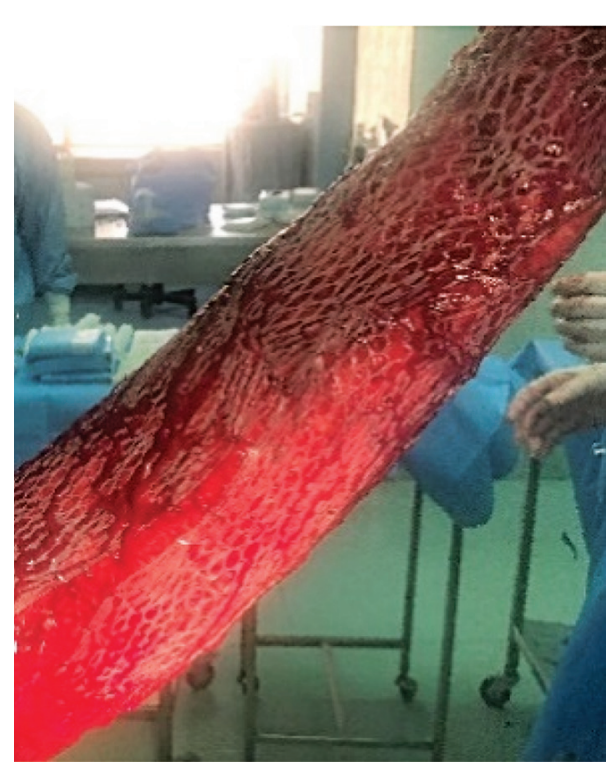

تصوير سا - زخم سوختكى در اثر ماده مذاب بلافاصله بعد از دبر يدمان و كرافت

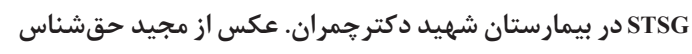

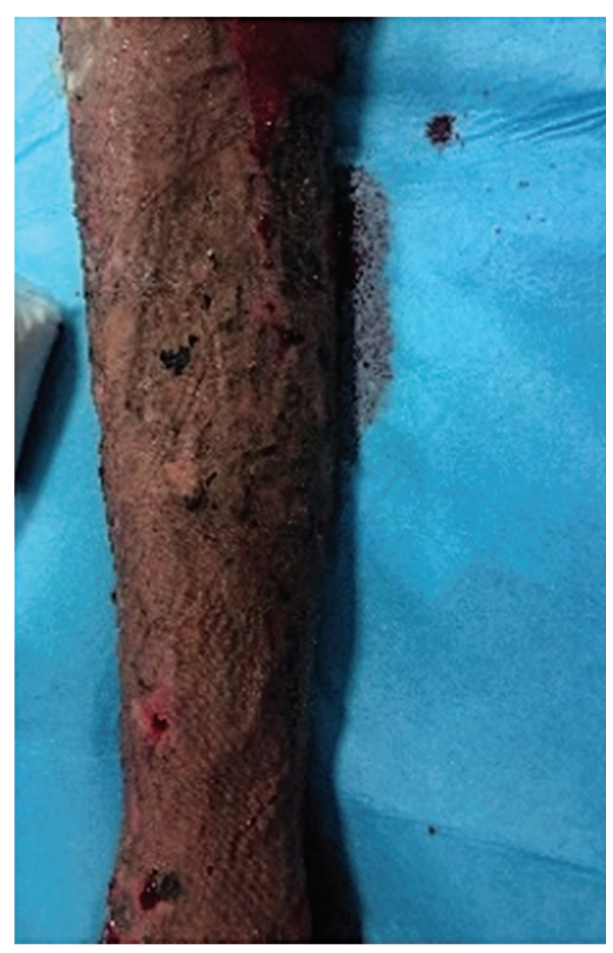

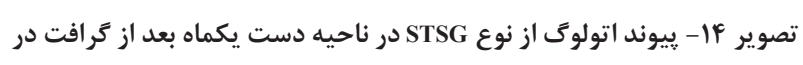

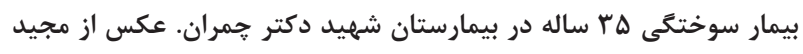
حقشناس

يوستى به خصوص در بيماران سوختكى استفاده مىشود. به ويزه آنه

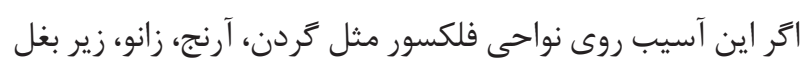

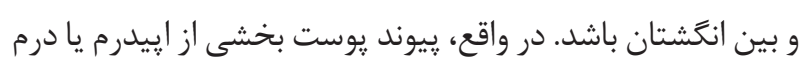

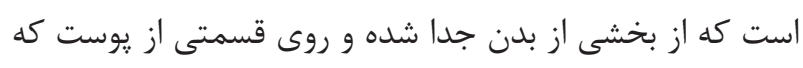

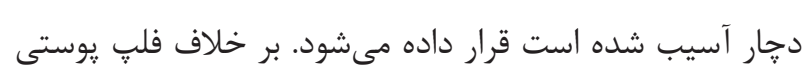




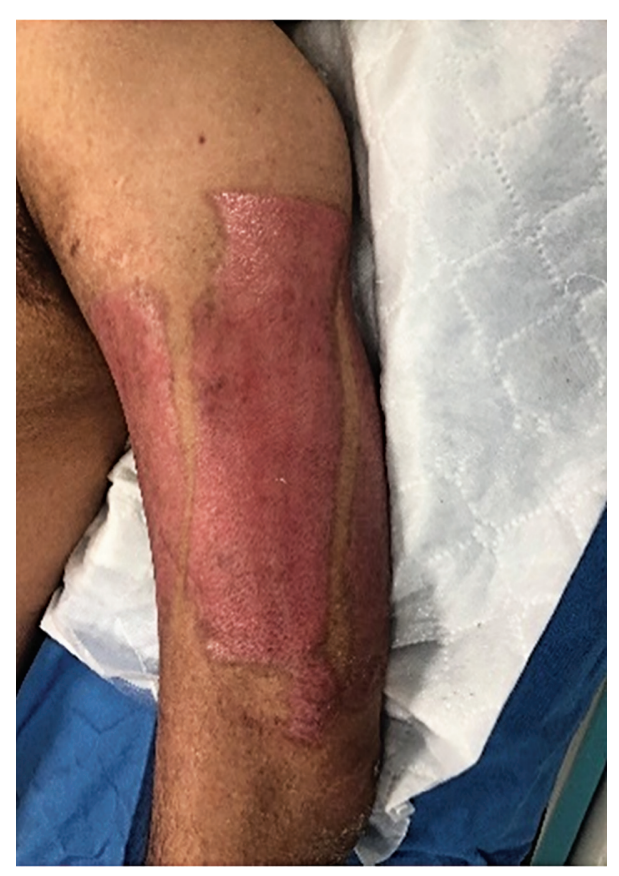

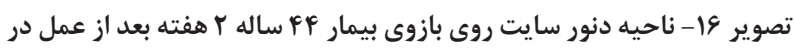

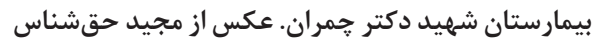

كننده خون به اطلاع :زشك معالج برسد. • سابقه هر ₹ونه حساسيت دارويى و غذايى بيمار بررسى زردد. سابقه هر گونه عفونت درگير در حال حاضر و يا عفونتهاى

$$
\text { مكرر بررسى گردد. }
$$

توانايىهاى عقلى و ذهنى بيمار براى همكارىهاى بعد از عمل بررسى گردد و آموزش هاى لازم به بيمار و خانواده وى

$$
\text { در مورد مراقبتهاى بعد از عمل داده شود. }
$$

بيمار بايستى حمام كرده و محل برداشت يوست عارى از مو باشد. بهتر است از موبر استفاده گردد در غير اين صورت توجه شود كه بريدگى و خراشيدگى ايجاد نشود.

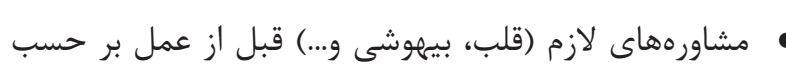
نظر ״زشك معالج انجام گردد. •آزمايشات خون، ادرار، تستهاى انعقادى و گرافى قفسه سينه قبل از عمل با دستور يزشك انجام گردد و در سوختگى ها و و عمل هاى وسيع نسبت به رزرو خون ايزوگروڤ اقدام گردد. حداقل به مدت T/ إعت بيمار ناشتا باشد. • با توجه به اينكه خارش يوستى جزئى از عوارض ترميم زخم rvi است، نسبت به كوتاه كردن ناخنها قبل از عمل جهت جلو

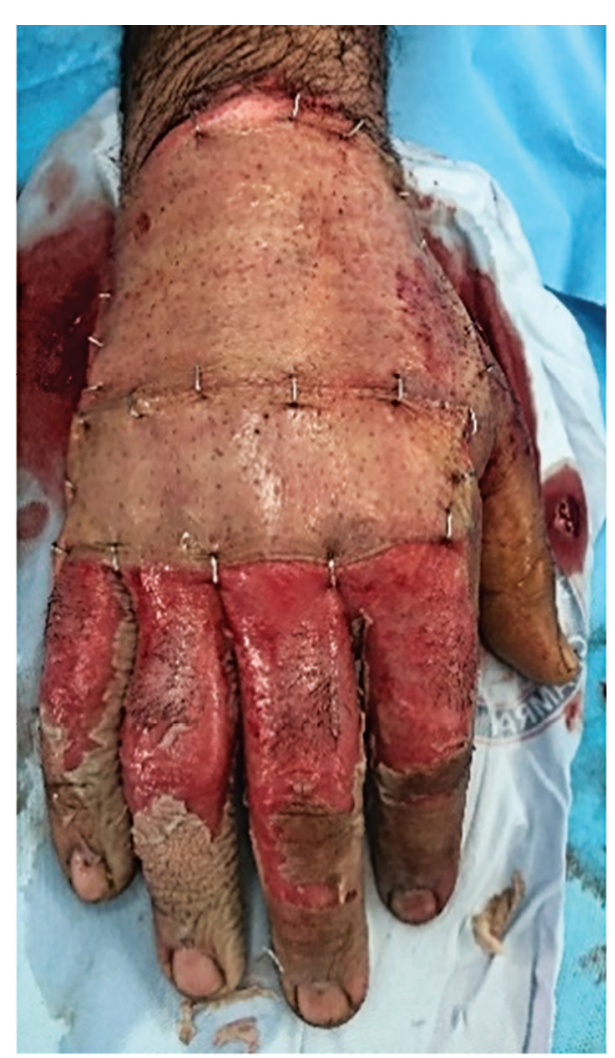

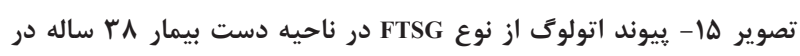

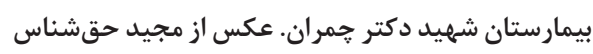

يا قسمت داخلى بازو انتخاب مىشوند. براى آسيبهاى وسيعتر، يك محل برداشت با سطح صاف و بزرى براى برداشت يك يوست بارت

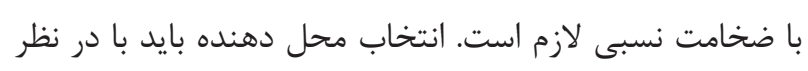
كرفتن سطح نياز به ي ييوند يوست و داشتن قابليت يوشش محل

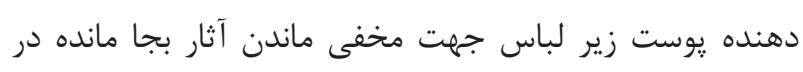
يوست، حفظ زيبايى و همجنين سهولت دسترسى به آن براى

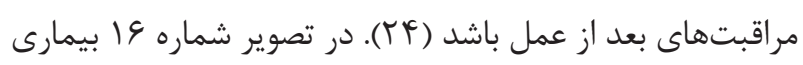
هر MF و به علت در دسترس نبودن نواحى مناسب از دست بيمار جهت برداشت يوست استفاده شد. مراقبتهاى قبل از عمل يِيوند يوست •قبل از انجام هر گونه اقدام جراحى بايد ابتدا تاريخجه از بيمار و يا همراهان درجه ا زرفته شود. اولويت ابتدا خود بيمار است و در صورت عدم همكارى بيمار، از همراهان وى يرس

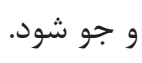
• سابقه مصرف دارويى و به خصوص آسيرين و يا داروهاى رقيق 


$$
\text { قرار گيرد. }
$$

مراقبت از محل دهنده پيوست

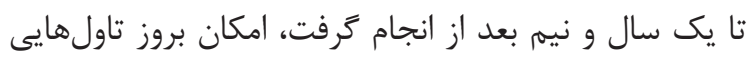
حاوى ترشحات زرد رنغ وجود دارد. بايد به بيمار اين اطمينان

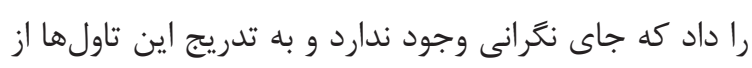

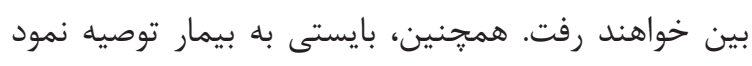

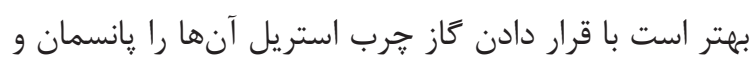

$$
\text { از دست كارى آنها خوددارى نمايد. }
$$

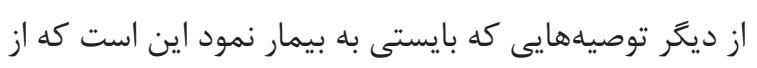

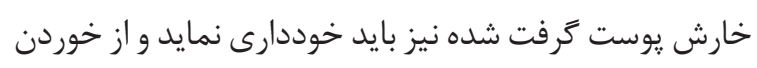

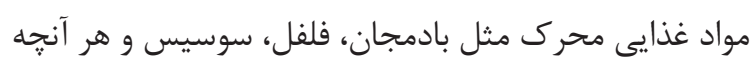

$$
\text { بدان حساسيت دارد خوددارى نمايد. }
$$

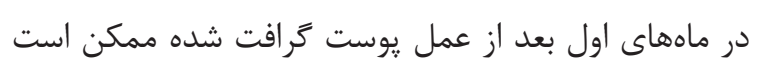

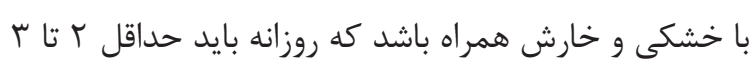

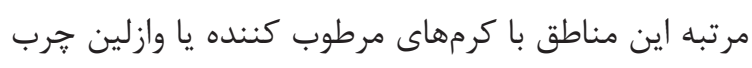
كردد.

جهت تسريع در ترميم زخمها توصيه به مصرف غذاهاى يريروتئين و مايعات فراوان مى كردد. در كوتاهترين زمان يس از اطمينان از موفقيت آميز بودن فئن هيوند يوست فيزيوترايى زير نظر متخصص مربوطه آغاز كردد.

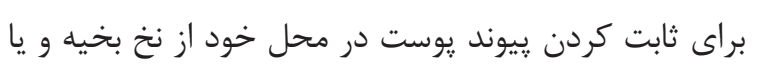
در اكثر موارد منگَنه فلزى استفاده مىشود. بخيه ها و منكُنهها

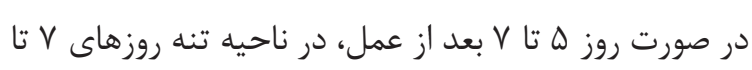

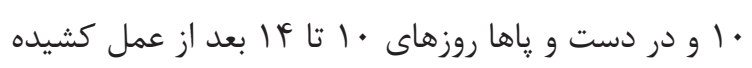

$$
\text { مىشوند. }
$$

از تابش نور آفتاب به زخم و يا قسمتهاى بهبود يافته جدا

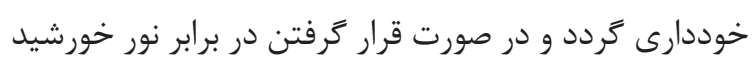

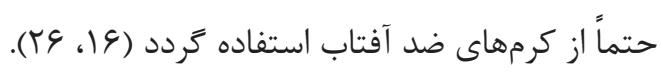

\section{الف) ابزارهاى اصلى جراحى مورد استفاده در بييوند يوست}

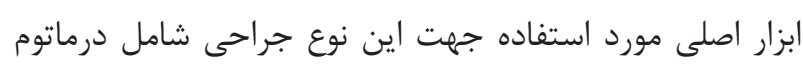
و مش گرفت و استبلر يوستى (Dermatome)

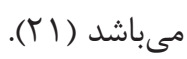
درماتوم ابزار جراحى مورد استفاده براى توليد برشى از يوست

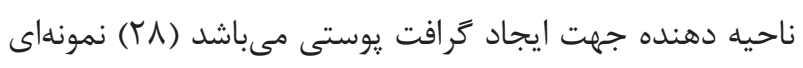

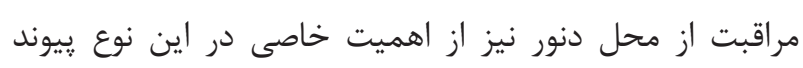

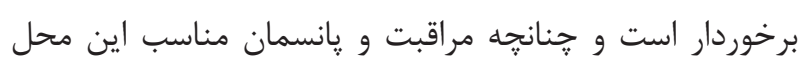

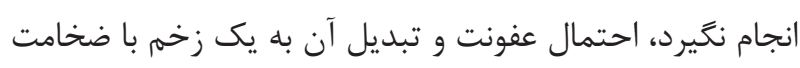

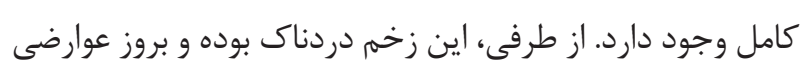

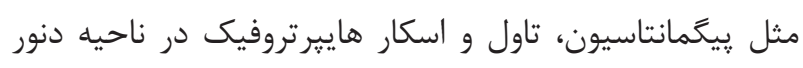

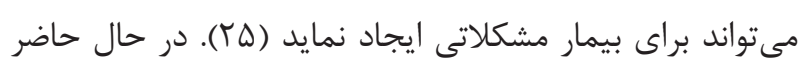

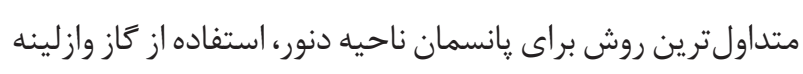

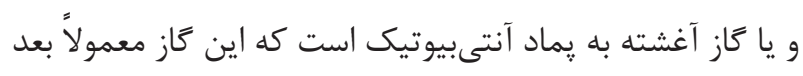

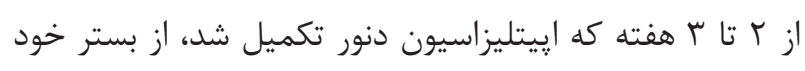

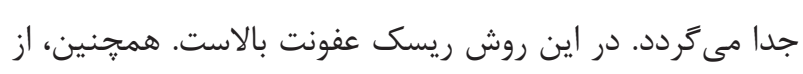

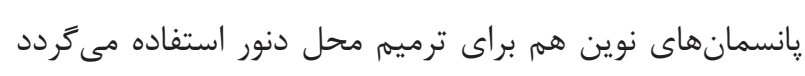
كه به مراتب نتايج بهترى دارد، ولى هزينههاى آن بالاست (IV (IV). امروزه از بردههاى آمنيون نيز براى محل دنور استفاده مى كنند.

مراقبت از محل دنور جهت ترميم سريعتر و بيشَّيرى از عوارض بايد به بيمار توصيه نمود: با توجه به شروع خونرسانى به ناحيه گرفت توسط بافت

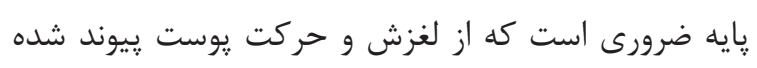

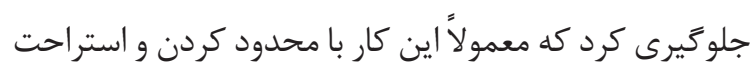

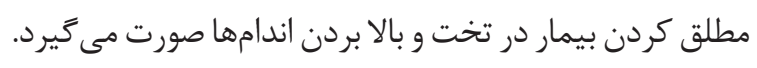

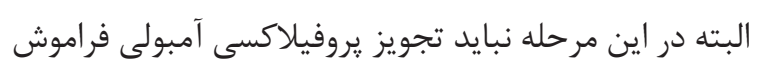

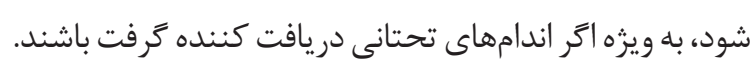

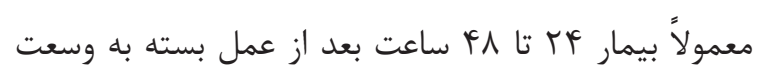

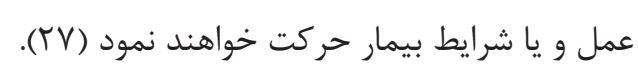

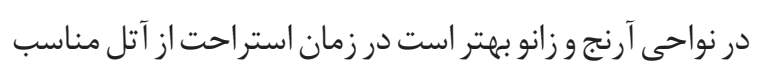
جهت جلوكيرى از خميده نكه داشتن اين مفاصل استفاده كرد.

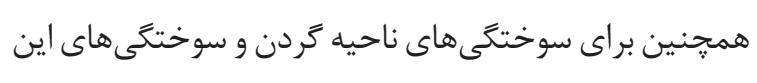

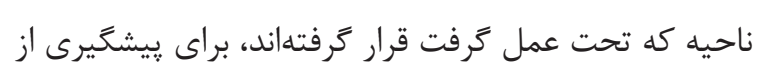

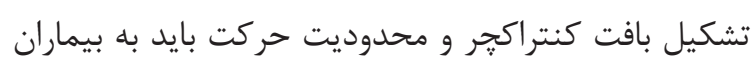

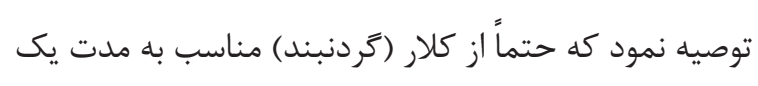

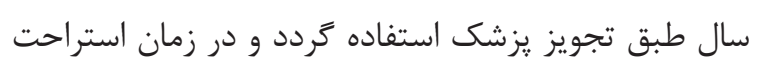
زير سر بالش قرار ندهند و سر تخت در وضعيت كاملاً خوابيده 
استيلر يوستى دستخاهى است كه جهت قرار دادن گيرههاى

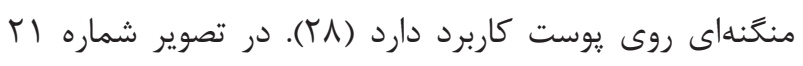
نمونهاى از اين دستغاه نشان داده شده است.

\section{( (Allograft) بيوند آلوَرفت}

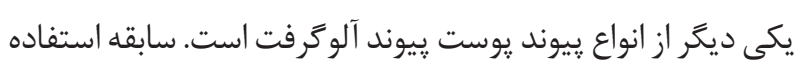

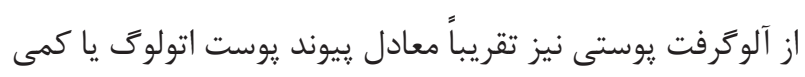

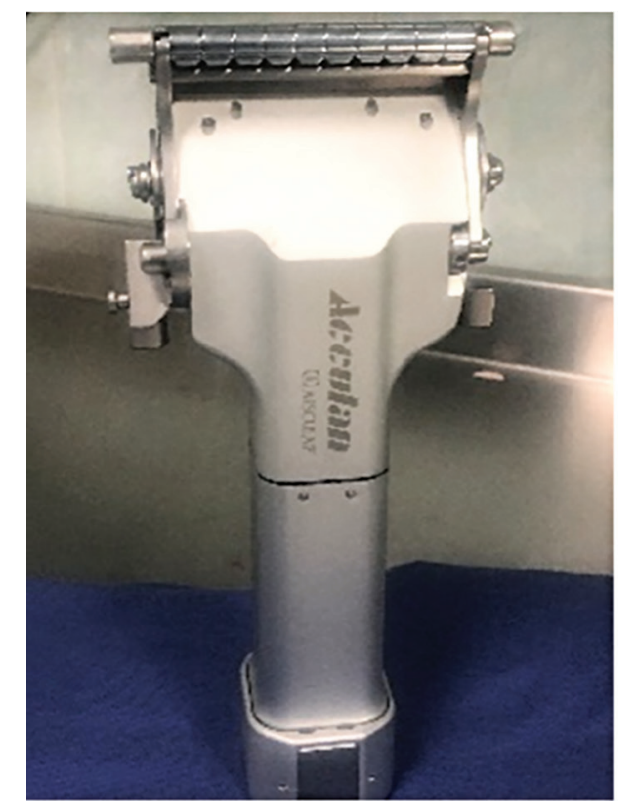

تصوير IV - درماتوم برقى در بيمارستان شهيد دكتر حمران. عكس از مجيد حقشناس

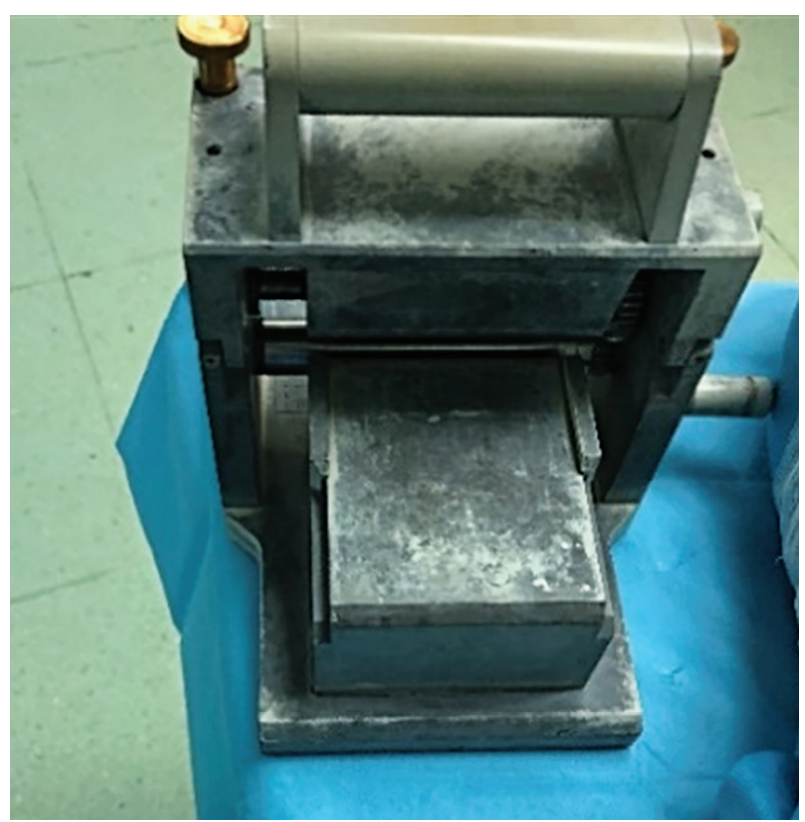

تصوير 19- مشكرفت در بيمارستان شهيد دكتر حمران. عكس از مجيد

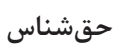

از درماتومهاى برقى (تصوير IV) و درماتوم دستى (تصوير IN) در زير نشان داده شده است.

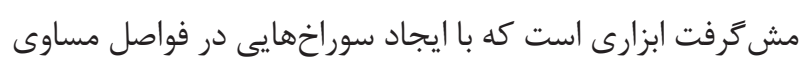

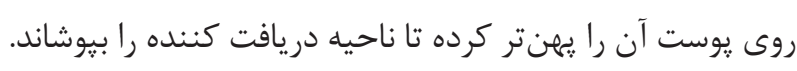
ميزان گسترش يوست به يليت (Plateau) بستخى دارد كه تا 9 برابر

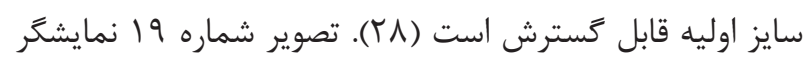

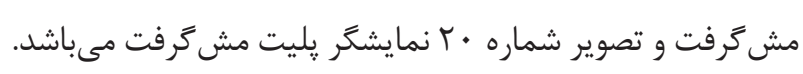

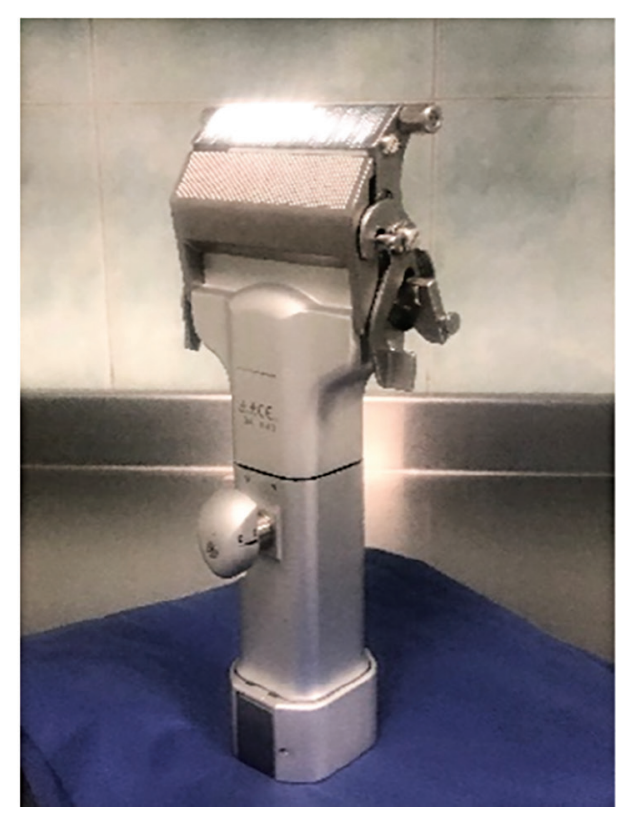

تصوير IV- D درمانوم برنى در بيمارست

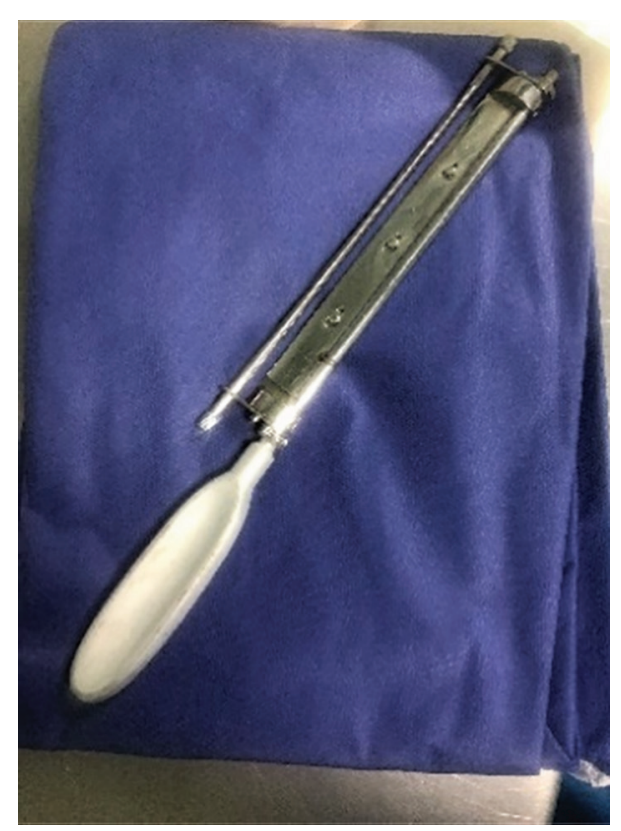

تصوير 11 - درماتوم دستى در بيمارستان شهيد دكتر جمران عكس از مجيد

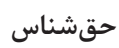


روشهاى نكمهدارى از آن، استفاده از آن توسعه بيشترى بيدا كرد.

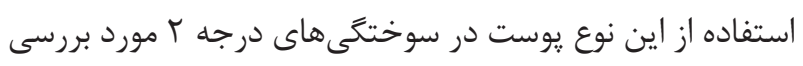

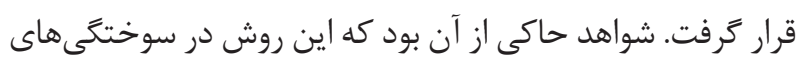

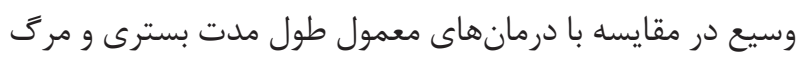

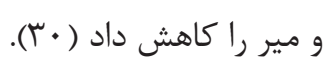

\section{(Tenograft) بيوند زنوَرفت}

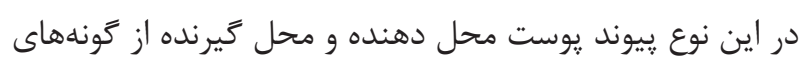

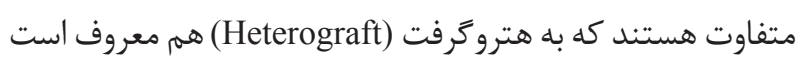

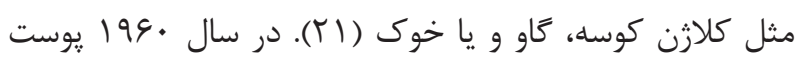

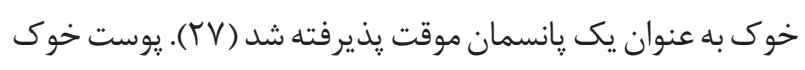

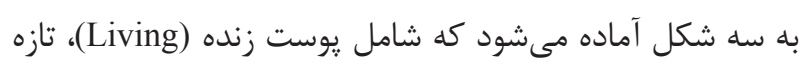
و يخ زده خشك بدون سلول (Fresh) نتايج برخى از تحقيقات نشان دادهاند كه هرَّ نوع داراى اثرات

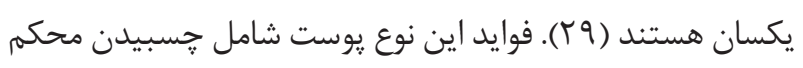
به بستر زخم (·ץ)، يوشاندن انتهاى اعصاب محيطى كه باعث كاهش درد محل مى

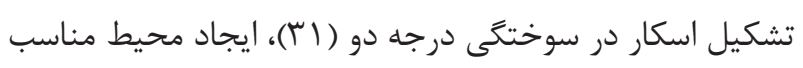

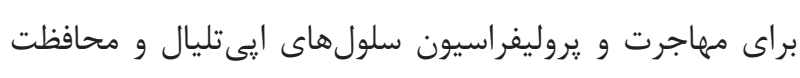
از زخم در برابر باكترىها مىباشد. به نظر مىرسد عملى ملكرد

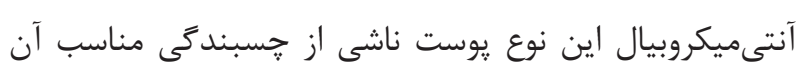

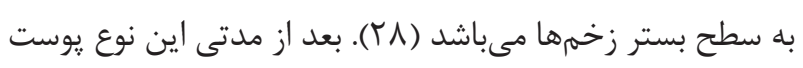

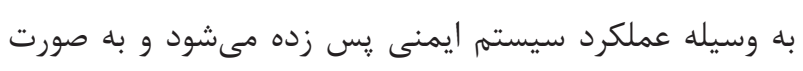

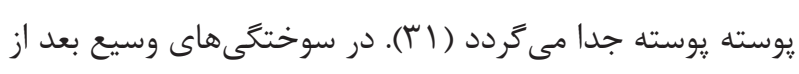

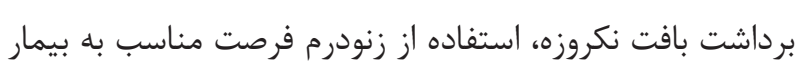

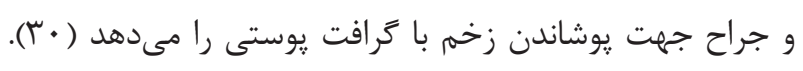

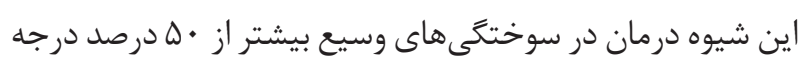

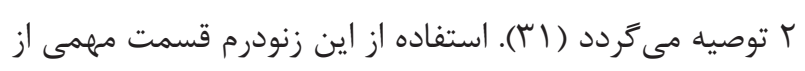

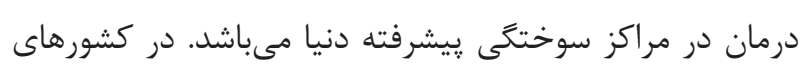

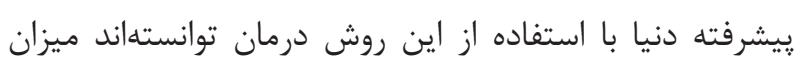

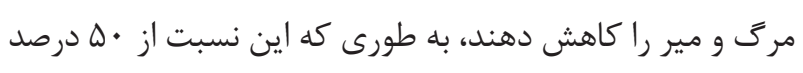

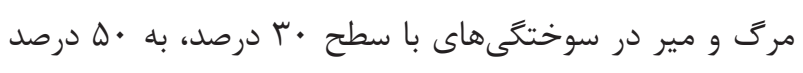

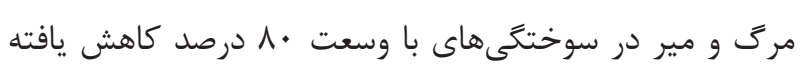

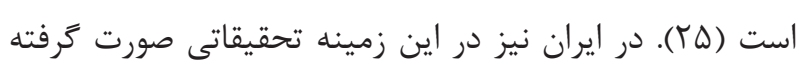

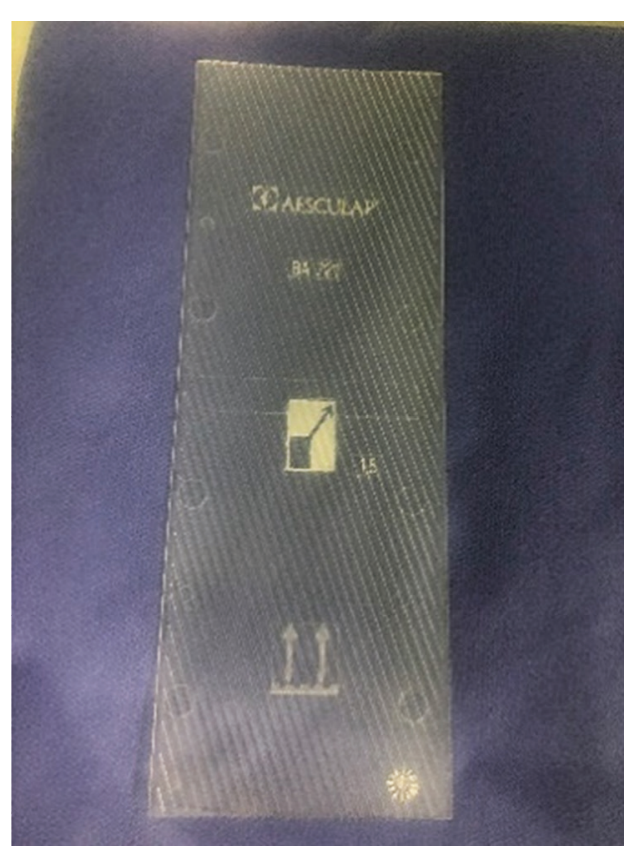

تصوير •r- بِليت مش كرفت در بيمارستان شهيد دكتر حمران. عكس از مجيد حقشناس تصوير

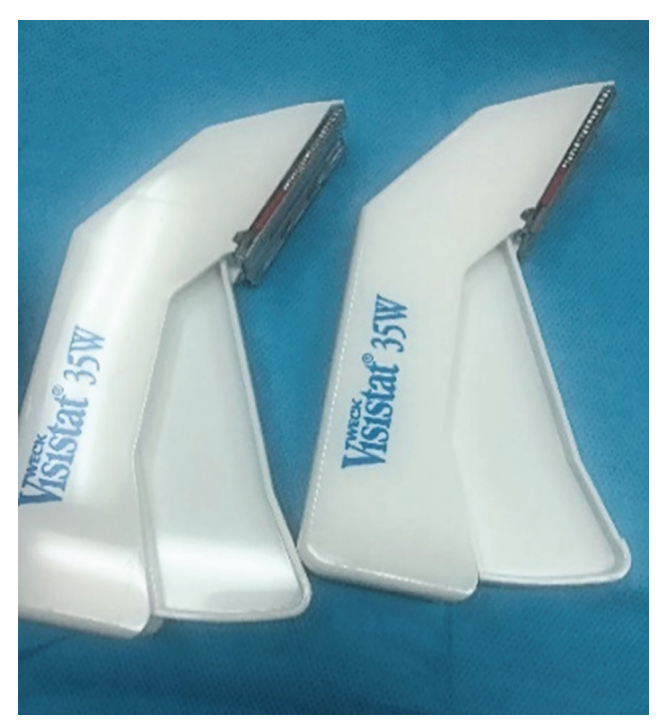

تصوير آس- استبلر يوستى در بيمارستان شهيد دكتر حمران. عكس از مجيد حقشناس

كمتر از آن است (Y9). در اين نوع بيوند دنور و محل كيرنده از

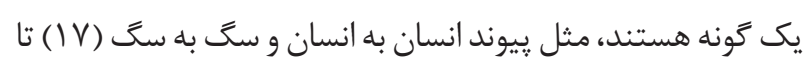

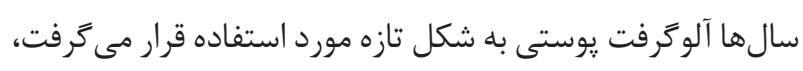

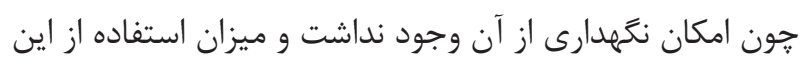

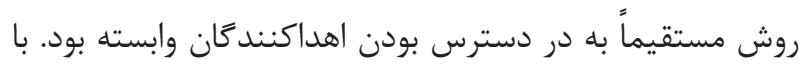

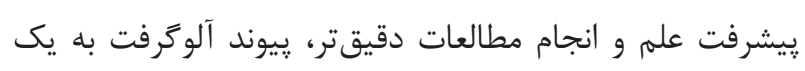

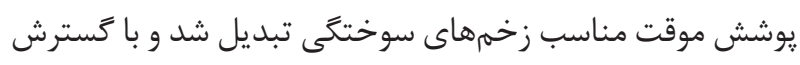


شرايطى را در زخم ايجاد مى كنند، مايع زل مانندى كه حاوى

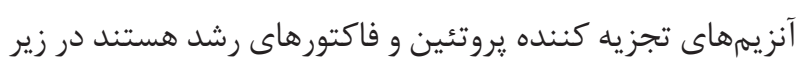

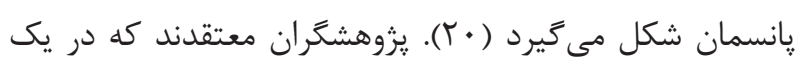

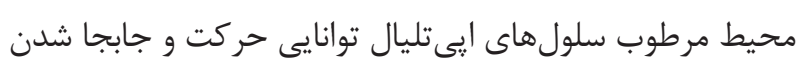

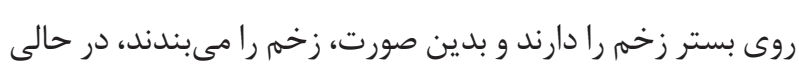

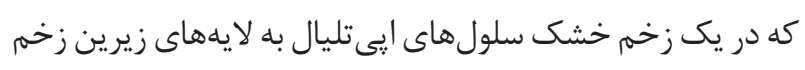

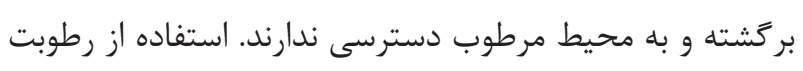

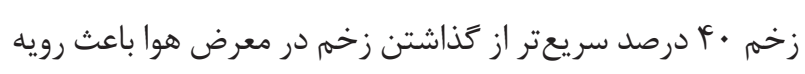

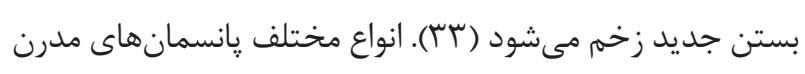

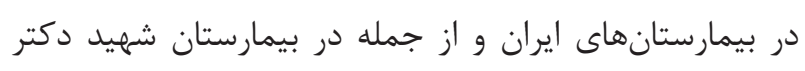

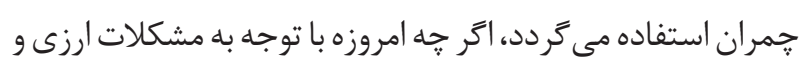

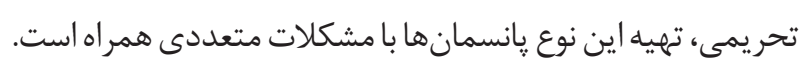

\section{بحث و نتيجه}

در اين مطالعه سعى شد كه با توجه به اهميت سوختگى دري دري

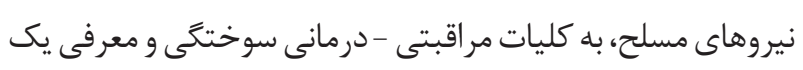

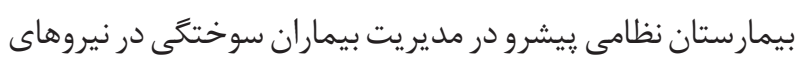

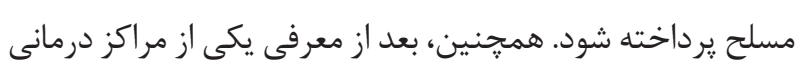

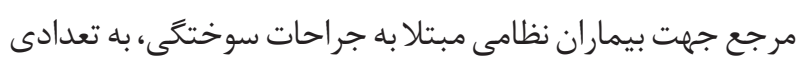

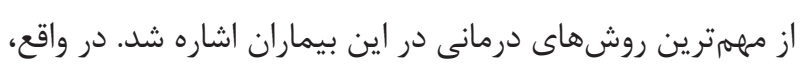

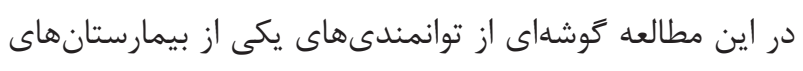

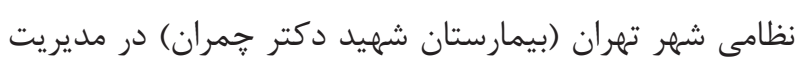

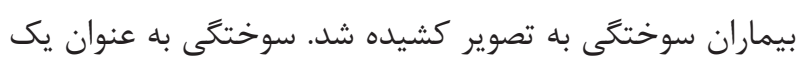

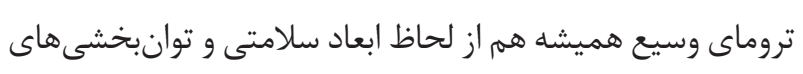

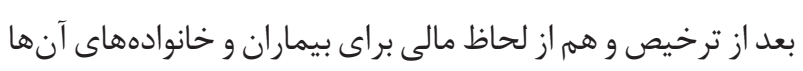

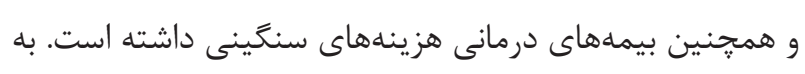

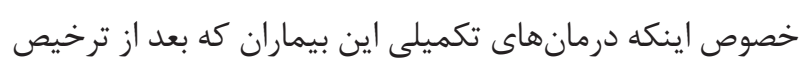

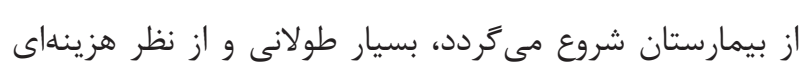
سرسامآور است. لذا، توصيه مىشود جهت حمردان حمايت از بيماران

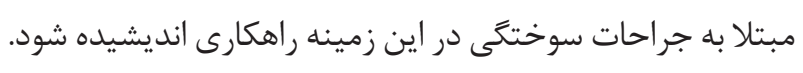

\section{تضاد منافع}

بدين وسيله نويسندكان تصريح مىنمايند كه هينج گَونه تضاد منافعى در خصوص يزوهش حاضر وجود ندارد.
است. به طور مثال، در يك مطالعه تجربى كه روى \1 ابيمار با

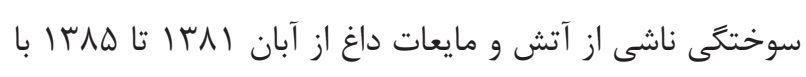

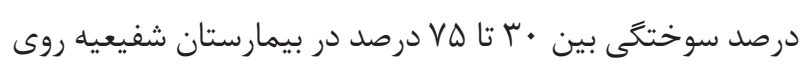

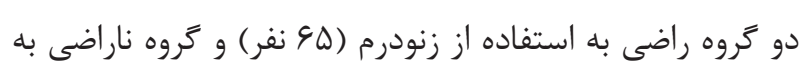

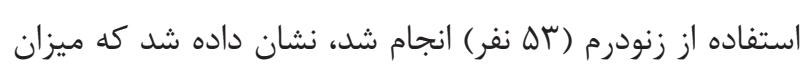

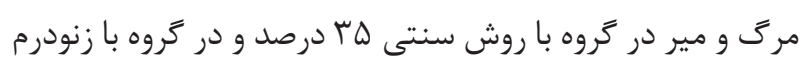
1/ • ا درصد بوده است كه خود نشان دهنده كاهش مرك ور و مير،

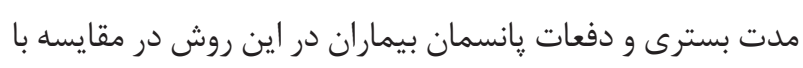

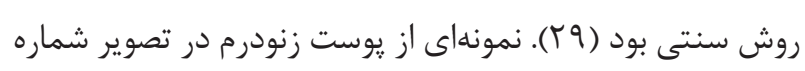

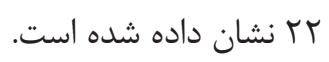

يانسمان هاى مدرن جهت درمان مؤثر زخم، انتخاب پانسمان مناسب در كنار ساير

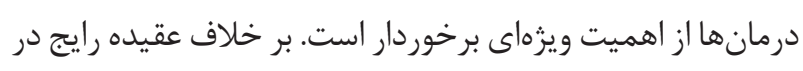
خصوص خشك نحَه داشتن زخم براى التيام سريعتر، يزوهشكران

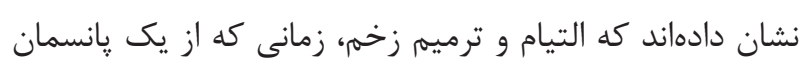

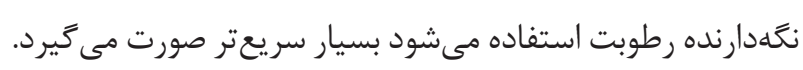

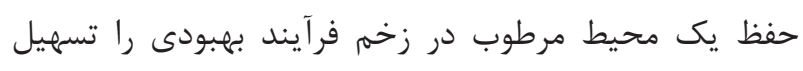

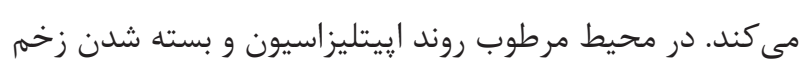

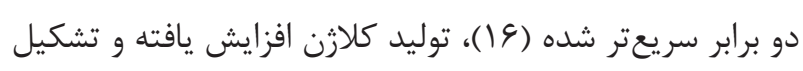

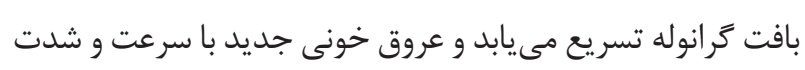

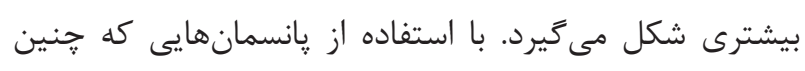

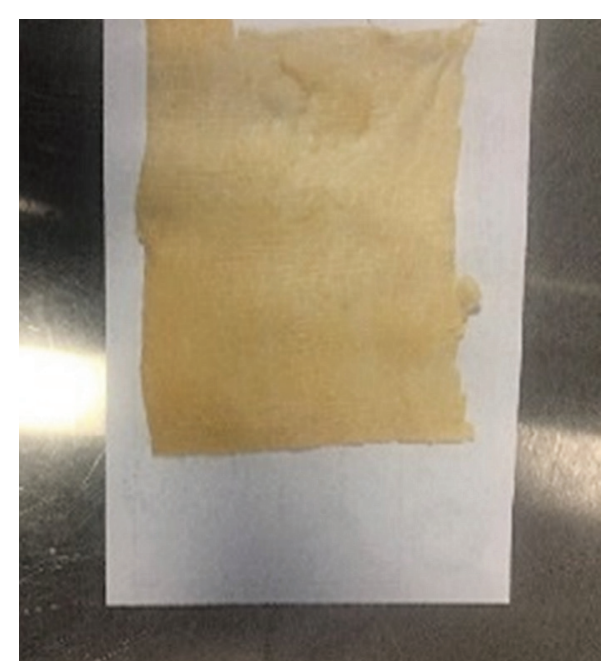

تصوير זr- يوست زنودرم در بيمارستان شهيد دكتر جمران عكس از مجيد

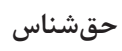




\section{Reference}

1- Mahmoudzadeh A, Ghaazi I, Askari M. Investigating and evaluating the worn-out texture of Ilam City with the approach of earthquake crisis management. Scientific-Research Quarterly of Geographical Data (SEPEHR). 2017; 26(102): 111-26.

2- Fatemi M, Samimi R, Saberi M. Quality of life of burn patients after discharge from Shahid Motahari Hospital in 2013. Iranian Journal of Surgery. 2015; 23(2): 31-40.

3- Olaitan P, Olaitan J. Burns and scalds-epidemiology and prevention in a developing country. Nigerian J Med. 2006; 14(1). DOI: 10.4314/njm.v14i1.37128 PMID: 15832636

4- World Health Organization. Burn prevention: success stories and lessons learned 2011 [cited 2019 Sep 02]. Available from: https:// apps.who.int/iris/handle/10665/97938.

5- Naghavi M, Abolhassani F, Pourmalek F, Moradi Lakeh M, Jafari $\mathrm{N}$, Vaseghi S, et al. The burden of disease and injury in Iran 2003. Population Health Metrics. 2009;7(1). DOI: 10.1186/1478-79547-9 PMID: 19527516

6- Iranian Legal Medicine Organization. Statistics Information of dead burn patient in Iran 2018 [cited 2019 Sep 1]. Available from: http://www.lmo.ir/web_directory/54002-\%D8\%B3\%D9\%88\%D8 \%AE\%D8\%AA\%DA\%AF\%DB\%8C.html.

7- Saberi M, Fatemi M, Soroush M, Masoumi M, Niazi M. Burn epidemiology in Iran: A meta-analysis study. Iranian Journal of Surgery. 2016;24(1):47-61.

8- Cancio L, Horvath E, Barillo D, Kopchinski B, Charter K, Montalvo A, et al. Burn Support for Operation Iraqi Freedom and Related Operations, 2003 to 2004. J Burn Care \& Rehabilitation. 2005;26(2):151-61. DOI: 10.1097/01.bcr.0000155540.31879.fb PMID: 15756117

9- Sidel'nikov V, Paramonov B, Tatarin S. Medical care for the burnt in modern local military conflicts. Voen Med Zh. 2002;323(7):359. PMID: 14982002

10- Church D, Elsayed S, Reid O, Winston B, Lindsay R. Burn Wound Infections. Clinical Microbiology Reviews. 2006;19(2):403-34. DOI: 10.1128/cmr.19.2.403-434.2006 PMID: 16614255

11- Treharne L, Kay A. The Initial Management of Acute Burns. J Royal Army Med Corps. 2001;147(2):198-205. DOI: 10.1136/ jramc-147-02-15 PMID: 11464415

12- Renz E, Cancio L, Barillo D, White C, Albrecht M, Thompson C, et al. Long Range Transport of War-Related Burn Casualties. J Trauma: Injury, Infection, \& Critical Care. 2008;64(Supplement):S136-S45. DOI: 10.1097/TA.0b013e31816086c9 PMID: 18376156

13- Azarmi S, Farsi Z. Roy's Adaptation Model-Guided Education and Promoting the Adaptation of Veterans With Lower Extremities Amputation. Iranian Red Crescent Med J. 2015;17(10). DOI: 10.5812/ircmj.25810 PMID: 26568861

14- History of Chamran Hospital. [cited 2019 Sep 01]. Available from: http://chamranhospital.ir/info/4.

15- Tintinalli J, Stapczynski J, Ma O, Yealy D, Meckler G, Cline D. Tintinallis emergency medicine: A comprehensive study guide.
2016.

16- Herndon D. Total Burn Care E-Book: Expert Consult-Online: Elsevier Health Sciences; 2012.

17- Herndon D. Total burn care: Elsevier Health Sciences; 2007.

18- Edgar D, Brereton M. Rehabilitation after burn injury. Bmj. 2004;329(7461):343-5. DOI: 10.1136/bmj.329.7461.343 PMID: 15297346

19- Ahuja R, Gibran N, Greenhalgh D, Jeng J, Mackie D, Moghazy A, et al. ISBI Practice Guidelines for Burn Care. Burns. 2016;42(5):9531021. DOI: 10.1016/j.burns.2016.05.013 PMID: 27542292

20- Bousfield C. A phenomenological investigation into the role the clinical nurse specialist. J Advanced Nursing. 2008;25(2):245-56. DOI: 10.1046/j.1365-2648.1997.1997025245.x PMID: 9043997

21- Mathes SJ. Plastic surgery: Saunders; 2006.

22- Moreo K. Understanding and overcoming the challenges of effective case management for patients with chronic wounds. The Case Manager. 2005;16(2):62-7. DOI: 10.1016/j. casemgr.2005.01.014 PMID: 15818347

23- Ratner D. Skin grafting. Seminars in Cutaneous Medicine and Surgery. 2003;22(4):295-305. DOI: 10.1016/s10855629(03)00079-8 PMID: 14740962

24- Tandon R, Agrawal K, Narayan R, Tiwari V, Prakash V, Kumar S, et al. Firecracker injuries during Diwali festival: The epidemiology and impact of legislation in Delhi. Indian J Plastic Surg. 2019;45(01):097-101. DOI: 10.4103/0970-0358.96595 PMID: 22754162

25- Barret-Nerin J, Herndon D. Burn Wound Management and Preparation for Surgery. Principles and Practice of Burn Surgery: CRC Press. 2004:97-114. DOI: 10.1201/b21634

26- Hexsel C, Loosemore M, Goldberg L, Awadalla F, Morales-Burgos A. Postauricular Skin. Dermatologic Surgery. 2015;41(1):48-52. DOI: 10.1097/dss.0000000000000218 PMID: 25545179

27- Brunner L. Brunner \& Suddarth's textbook of medical-surgical nursing. Lippincott Williams \& Wilkins. 2016.

28- Salehi S, As'adi K, Mousavi S, Shoar S. Evaluation of Amniotic Membrane Effectiveness in Skin Graft Donor Site Dressing in Burn Patients. Indian J Surg. 2013;77(S2):427-31. DOI: 10.1007/ s12262-013-0864-x PMID: 26730039

29- Hosseini S, Mousavinasab S, Rahmanpour H, Fallahnezhad M. The biological dressing versus conventional treatment in massive burns: a prospective clinical trial. Tehran univ Med J. 2007;65(6):36-41. DOI: 10.1186/isrctn01055688 PMID: 19353315

30- Ghardashi F, Akbarzadeh R. To be familiar with operation instrument. Iran: Salemi, Jamehnegar; 2010.

31- Hosseini S, Mousavinasab S, Rahmanpour H, Fallahnezhad M. A biological dressing versus 'conventional'treatment in patients with massive burns: a clinical trial. Turkish Journal of Trauma \& Emergency Surgery. 2009;2:135-40. DOI: 10.1186/ isrctn01055688 PMID: 19353315 